\title{
OCCUPATIONAL EXPOSURE ASSESSMENT FOR CRYSTALLINE SILICA DUST: APPROACH IN POLAND AND WORLDWIDE
}

\author{
ALEKSANDRA MACIEJEWSKA \\ Nofer Institute of Occupational Medicine, Department of Environmental Health Hazards \\ Łódź, Poland
}

\begin{abstract}
Crystalline silica is a health hazard commonly encountered in work environment. Occupational exposure to crystalline silica dust concerns workers employed in such industries as mineral, fuel-energy, metal, chemical and construction industry. It is estimated that over 2 million workers in the European Union are exposed to crystalline silica. In Poland, over 50 thousand people work under conditions of silica dust exposure exceeding the occupational exposure limit. The assessment of occupational exposure to crystalline silica is a multi-phase process, primarily dependent on workplace measurements, quantitative analyses of samples, and comparison of results with respective standards. The present article summarizes the approaches to and methods used for assessment of exposure to crystalline silica as adopted in different countries in the EU and worldwide. It also compares the occupational limit values in force in almost 40 countries. Further, it points out the consequences resulting from the fact that IARC has regarded the two most common forms of crystalline silica: quartz and cristobalite as human carcinogens. The article includes an inter-country review of the methods used for air sample collection, dust concentration measurements, and determination of crystalline silica. The selection was based on the GESTIS database which lists the methods approved by the European Union for the measurements and tests regarding hazardous agents. Special attention has been paid to the methods of determining crystalline silica. The author attempts to analyze the influence of analytical techniques, sample preparation and the reference materials on determination results. Also the operating parameters of the method, including limit of detection, limit of quantification, and precision, have been compared.
\end{abstract}

Key words:

Crystalline silica, Quartz, Occupational exposure assessment, Limit value, X-ray diffraction, Infrared spectrophotometry

\section{INTRODUCTION}

Silica (silicon dioxide) is a common name of several minerals and an amorphous substance. Silicon and oxygen that make silica are the two most widespread elements in the Earth's crust. In the natural environment, silica is primarily found either in the evidently crystalline or cryptocrystalline form, and sometimes in an amorphous form. A common crystalline form of $\mathrm{SiO}_{2}$ is quartz, the most thermodynamically stable polymorph under ambient conditions. The forms crystallizing at higher temperatures, namely cristobalite and tridymite, are much more scarce. Still less common forms are moganite and melanophlogite, as well as the high-temperature and high-pressure polymorphs: coesite, keatite and stishovite, practically not encountered in nature. The cryptocrystalline forms include chalcedony, agate, flint, jasper and others. All the crystalline forms of silica are referred to as "free crystalline silica" [1]. Quartz makes up $12 \%$ of the lithosphere and is an important element of all kinds of rocks: igneous, sedimentary, and metamorphic, as well as of the soils. It is almost the only component of solid rocks, such as sandstone or quartzite, loose rocks, and sand and gravel, that are the basic source of silica in industry. Quartz is characterized by high chemical resistance; it can be dissolved only in hydrofluoric acid and, at high temperatures, also in hydroxide and alkaline carbonates. Moreover, it has a particularly

Received: November 12, 2007. Accepted: February 29, 2008.

Address reprint requests to: A. Maciejewska, Department of Environmental Health Hazards, Nofer Institute of Occupational Medicine, św. Teresy 8, 91-348 Łódź, Poland (e-mail: altema@.imp.lodz.pl). 
high hardness -7 on the Mohs scale, and a high melting point $-1713^{\circ} \mathrm{C}$. Its ubiquity in the natural environment as well as the specific physicochemical properties make quartz widely used in the industry. In Poland, apart from quartzite and sandstone, almost 4 million tons of quartz sand and silica sand are mined every year [2].

Crystalline silica in work environment has long been known to be harmful to human health. Long-term breathing of fine dust particulates of the respirable fraction is associated with the development of silicosis. Exposure to silica is one of the etiological factors of coal miners' pneumoconiosis. Moreover, it can contribute to an increased incidence rate of respiratory diseases such as chronic bronchitis and pulmonary emphysema, and of immunological disorders and chronic kidney disfunction [3-5].

Occupational exposure to crystalline silica refers mainly to mining, construction, agriculture, and industry. Exposure to quartz dust can be primarily encountered at the following worksites:

- in quarries, coal mines and raw mineral mines of chemical resources and metal ores;

- in ferrous and non-ferrous metal industry e.g. zinc and aluminum;

- in glassware plants manufacturing architectural glass, domestic glassware, lighting glass, optical glass, laboratory glassware, and glass fibers;

- in whiteware ceramics, sanitary and technical ware, and faience industry;

- in plants producing ferrosilicon, other silicon alloys and metallic silicon;

- in building stone and building material works (concrete, plaster work, mortar);

- at industrial and housing construction sites;

- at road and tunnel construction sites;

- in refractory and abrasive material works;

- in production of chemicals for chemical industry: sodium silicate, silicones, sealants and binders, paints (ceramic color), rubber, fertilizers and pesticides;

- in electric power stations and heating plants using coal;

- in workshops processing precious and semiprecious silica stones;
- in agriculture and gardening.

Exposure to other forms of crystalline silica: cristobalite and tridymite usually takes place under conditions of technological processes involving roasting at temperatures of at least $1000^{\circ} \mathrm{C}$, or roasting of raw materials containing quartz, kaolin or amorphous silica (e.g. diatomaceous earth, siliceous earth, and diatomites). Cristobalite dust exposure may occur in the plants manufacturing refractories, abrasive materials, ceramic ware and faience, paints, and catalysts for chemical industry, as well as pesticides and fertilizers when natural silica materials are used as fillers.

The workers exposed to the highest concentrations of crystalline silica dust include:

— workers employed to bore tunnels;

- workers performing tasks involving crushing, cutting, grinding or drilling rock and building materials (e.g. concrete) in mines, as well as in rooms with inefficient ventilation;

- workers performing tasks related to abrasive cleaning of large surfaces, with the use of sand;

- workers involved in pouring liquid silica materials;

- workers cleaning castings and repairing high-temperature furnaces;

- workers performing dry processing of ceramic ware, refractories and abrasive products $[3,6,7]$.

In the European Union, the number of workers exposed to crystalline silica, except for coal miners, is estimated to be over 2 million [8], and the data collected for many years at the national databases: COLCHIC in France [9] and MEGA in Germany [10], provide evidence that the determination of crystalline silica is one of the most prevalent analyses conducted in work environment. In Poland, according to the statistics of GUS (Central Statistical Office), over 50 thousand people [2] are exposed to industrial dust at levels exceeding occupational exposure limits, which are the conditions conducive to the development of lung fibrosis. The actual number of thus exposed workers is higher since the GUS statistics do not include enterprises employing less than 10 workers. 


\section{APPROACH TO OCCUPATIONAL EXPOSURE ASSESSMENT FOR CRYSTALLINE SILICA DUST}

The assessment of occupational exposure to chemical agents harmful to human health, including free crystalline silica, is a multi-phase process. At the initial stage, it consists in collecting information on the technological processes and organization of work in a given workplace, and identifying the potential sources of exposure. Then comprehensive field measurements are carried out to determine the concentration of a given agent, evaluate the hygienic conditions in workplace and compare them with relevant occupational exposure limits. In Poland, like in many other European countries, this process of occupational exposure assessment is conducted according to the general strategy for measurements of workplace hazards, and the guidelines included in the PN-EN-689:2002 standard [11]. On the other hand, the exposure assessment criteria, defining also the necessary testing procedures, include the limit values for the concentration of hazardous substances.

\section{LIMIT VALUES FOR WORKPLACE CONCENTRATIONS OF CRYSTALLINE SILICA DUST}

No uniform international system of setting the limit values for workplace concentrations of hazardous agents has as yet been established. Moreover, there is even no common definition of the limit value or of the safety level with respect to occupational exposure. The setting of the limit values is based on two levels: the safety level (assumed to protect all the exposed workers against health effects) and the border level (assumed to provide safety to almost all the exposed workers except for individuals with increased susceptibility to adverse effects of a given hazard). In practice, the limit values are implemented mostly on the basis of a compromise between the health requirements and the technical possibility of satisfying them.

Leading organizations dealing with workers' health protection, like the American Conference of Governmental Industrial Hygienists (ACGIH) and the National
Institute for Occupational Safety and Health (NIOSH) in the USA, have worked out documentation and proposed standards based on analyzing the outcomes of the most recent research reported in world literature. The limit values recommended by these organizations make a reference point for defining the hygienic standards in other countries. Also the European Union has decided to develop a list of standards [12-14]. This example was followed by 50 countries, including Poland [15]. Table 1 presents the limit values for crystalline silica in workplace as promoted by ACGIH and NIOSH, as well as the standards adopted in more than 30 countries all over the world.

The standard values for crystalline silica are expressed in two ways. The most common method (used by ACGIH and NIOSH) involves quoting the limit mass of respirable fraction of crystalline silica dust or its polymorphs in $1 \mathrm{~m}^{3}$ of air collected in workplace, in relation to an 8-hour or 10-hour work shift and a 40-hour work week. Another method involves limiting the concentration of dust with a specified range of percentage content of crystalline silica, or calculating the standard value according to a given formula, taking into account the proportion of quartz or free crystalline silica. The limit values for crystalline silica (100\%) concentrations, defined in such a way, refer not to a single standard value expressed as the respirable dust mass in air volume, but they fall within a concentration range. In addition to the standards regarding respirable dust and based on the critical effects of exposure: fibrosis and silicosis, some countries, e.g. the USA (the legally-binding standards of the Occupational Safety and Health Administration (OSHA) and the standards in force in California), as well as Denmark, Greece, India, the Canadian province of Alberta, Norway, Hungary, Thailand, and Poland have also developed the standards for the total dust that consider the irritant effect of silica on the respiratory tract. On the other hand, such countries as Russia and Lithuania have decided to adopt the standard values for total dust concentrations only with respect to quartz and cristobalite exposure. The few existing limit values for crystalline silica concern the short-term exposure concentrations. 
Table 1. Occupational exposure limits for free crystalline silica

\begin{tabular}{|c|c|c|c|c|c|c|c|c|c|}
\hline \multirow[b]{2}{*}{ No. } & \multirow[b]{2}{*}{$\begin{array}{l}\text { Organiza- } \\
\text { tion/ } \\
\text { country }\end{array}$} & \multicolumn{7}{|c|}{ Limit values } & \multirow[b]{2}{*}{$\begin{array}{l}\text { Informa- } \\
\text { tion sourc }\end{array}$} \\
\hline & & $\begin{array}{l}\text { Exposure limit and } \\
\text { interpretation }\end{array}$ & $\begin{array}{l}\text { Crystalline silica } \\
\text { form }\end{array}$ & $\begin{array}{c}\text { Dust } \\
\text { fraction }\end{array}$ & $\begin{array}{l}\text { Limit value } \\
{\left[\mathrm{mg} / \mathrm{m}^{3}\right]}\end{array}$ & $\begin{array}{l}\text { Value } \\
\text { range } \\
\text { in refer- } \\
\text { ence } \\
\text { to } 100 \% \\
\mathrm{SiO}_{2}\end{array}$ & $\begin{array}{l}\text { Carcino- } \\
\text { genicity } \\
\text { remarks }\end{array}$ & $\begin{array}{l}\text { Year of } \\
\text { introduc- } \\
\text { tion } \\
\text { /publica- } \\
\text { tion }\end{array}$ & \\
\hline 1 & $\begin{array}{l}\text { ACGIH, } \\
\text { USA }\end{array}$ & $\begin{array}{l}\text { TLV - Threshold } \\
\text { Limit Value } \\
\text { (TWA-8h, 40-h } \\
\text { week) }{ }^{1}\end{array}$ & $\begin{array}{l}\text { crystalline } \\
\text { silica: } \alpha \text {-quartz } \\
\text { cristobalite }\end{array}$ & respirable & 0.025 & - & A2 & 2006 & 16,17 \\
\hline 2 & $\begin{array}{l}\text { NIOSH, } \\
\text { USA }\end{array}$ & $\begin{array}{l}\text { REL-Recom- } \\
\text { mended Exposure } \\
\text { Limit (TWA-10h, } \\
\text { 40-h week) }\end{array}$ & $\begin{array}{l}\text { quartz } \\
\text { cristobalite } \\
\text { tridymite }\end{array}$ & respirable & 0.05 & - & $\begin{array}{c}\mathrm{Ca} \\
\text { (NIOSH) }\end{array}$ & $\begin{array}{c}1974 \\
\text { (quartz) }\end{array}$ & 4,18 \\
\hline 3 & $\begin{array}{l}\text { European } \\
\text { Union }\end{array}$ & $\begin{array}{l}\text { IOELV - Indicative } \\
\text { Occupational Ex- } \\
\text { posure Limit Value } \\
\text { (TWA-8h) }\end{array}$ & $\begin{array}{l}\text { crystalline } \\
\text { silica }\end{array}$ & IOELV for & stalline silica 1 & t established & & & $12,13,14$ \\
\hline 4 & Argentina & $\begin{array}{l}\text { CMP - Concen- } \\
\text { tración Máxima } \\
\text { Permisible (TWA- } \\
\text { 8h, 40-h week) }\end{array}$ & $\begin{array}{l}\text { quartz } \\
\text { cristobalite } \\
\text { tridymite }\end{array}$ & respirable & 0.05 & - & quartz: A2 & 2003 & 19 \\
\hline 5 & Australia & $\begin{array}{l}\text { Exposure Standard } \\
\text { (TWA-8h) }\end{array}$ & $\begin{array}{l}\text { quartz } \\
\text { cristobalite } \\
\text { tridymite }\end{array}$ & respirable & 0.1 & - & no & 2004 & 20 \\
\hline 6 & Austria & $\begin{array}{l}\text { MAK - Maximale } \\
\text { Arbeitsplatz- } \\
\text { konzentrationen } \\
\text { (TWA-8h, 40-h } \\
\text { week) }\end{array}$ & $\begin{array}{l}\text { quartz } \\
\text { cristobalite } \\
\text { tridymite }\end{array}$ & respirable & 0.15 & - & no & 1992 & 21,22 \\
\hline \multirow[t]{2}{*}{7} & Belgium & $\begin{array}{l}\text { VLEP - Valeurs } \\
\text { Limites }\end{array}$ & quartz & respirable & 0.1 & - & no & 1995 & 21,23 \\
\hline & & $\begin{array}{l}\text { d'Exposition } \\
\text { Professionnelle }\end{array}$ & $\begin{array}{l}\text { cristobalite } \\
\text { tridymite }\end{array}$ & respirable & 0.05 & - & no & & \\
\hline 8 & Bulgaria & $\begin{array}{l}\text { Concentration limit } \\
\text { (TWA-8h) }\end{array}$ & $\begin{array}{l}\text { quartz } \\
\text { cristobalite } \\
\text { tridymite }\end{array}$ & respirable & 0.07 & - & no & 2003 & 24 \\
\hline \multirow[t]{7}{*}{9} & Canada: & & & & & & & & \\
\hline & Quebec & VEMP - Valeur & quartz & respirable & 0.1 & - & $\mathrm{C} 2$ & 1996 & 21,25 \\
\hline & & $\begin{array}{l}\text { D'Exposition Moy- } \\
\text { enne Pondérée } \\
\text { (TWA-8h) }\end{array}$ & $\begin{array}{l}\text { cristobalite } \\
\text { tridymite }\end{array}$ & respirable & 0.05 & & & & \\
\hline & Alberta & OEL - Occupation- & quartz & respirable & 0.1 & - & nd & 1988 & 26 \\
\hline & & al Exposure Limit & & total dust & 0.3 & & & & \\
\hline & & & $\begin{array}{l}\text { cristobalite } \\
\text { tridymite }\end{array}$ & respirable & 0.05 & & & & \\
\hline & & & $\begin{array}{l}\text { cristobalite } \\
\text { tridymite }\end{array}$ & total dust & 0.15 & & & & \\
\hline
\end{tabular}


Table 1. Occupational exposure limits for free crystalline silica — cont.

\begin{tabular}{|c|c|c|c|c|c|c|c|c|c|}
\hline \multirow[b]{2}{*}{ No. } & \multirow[b]{2}{*}{$\begin{array}{l}\text { Organiza- } \\
\text { tion/ } \\
\text { country }\end{array}$} & \multicolumn{7}{|c|}{ Limit values } & \multirow[b]{2}{*}{$\begin{array}{l}\text { Informa- } \\
\text { tion source }\end{array}$} \\
\hline & & $\begin{array}{l}\text { Exposure limit and } \\
\text { interpretation }\end{array}$ & $\begin{array}{l}\text { Crystalline silica } \\
\text { form }\end{array}$ & $\begin{array}{l}\text { Dust } \\
\text { fraction }\end{array}$ & $\begin{array}{l}\text { Limit value } \\
{\left[\mathrm{mg} / \mathrm{m}^{3}\right]}\end{array}$ & $\begin{array}{l}\text { Value } \\
\text { range } \\
\text { in refer- } \\
\text { ence } \\
\text { to } 100 \% \\
\mathrm{SiO}_{2}\end{array}$ & $\begin{array}{l}\text { Carcino- } \\
\text { genicity } \\
\text { remarks }\end{array}$ & $\begin{array}{l}\text { Year of } \\
\text { introduc- } \\
\text { tion } \\
\text { /publica- } \\
\text { tion }\end{array}$ & \\
\hline & $\begin{array}{l}\text { British } \\
\text { Colum- } \\
\text { bia }\end{array}$ & $\begin{array}{l}\text { OEL - Occupa- } \\
\text { tional Exposure } \\
\text { Limit (TWA-8h) }\end{array}$ & $\begin{array}{l}\alpha \text {-quartz } \\
\text { cristobalite }\end{array}$ & respirable & 0.025 & - & $\mathrm{A} 2$ & 2006 & 27 \\
\hline 10 & Chile & $\begin{array}{l}\text { LPP - Limite Per- } \\
\text { misible Ponderado }\end{array}$ & $\begin{array}{l}\text { quartz } \\
\text { cristobalite } \\
\text { tridymite }\end{array}$ & $\begin{array}{l}\text { respirable } \\
\text { respirable }\end{array}$ & $\begin{array}{l}0.08 \\
0.04\end{array}$ & - & no & 1992 & 28 \\
\hline 11 & $\begin{array}{l}\text { Czech } \\
\text { Republic }\end{array}$ & $\begin{array}{l}\text { OEL - } \\
\text { Occupational } \\
\text { Exposure Limit }\end{array}$ & $\begin{array}{l}\text { quartz } \\
\text { cristobalite } \\
\text { tridymite }\end{array}$ & respirable & 0.1 & - & nd & nd & 29 \\
\hline \multirow[t]{2}{*}{12} & \multirow[t]{2}{*}{ Denmark } & \multirow[t]{2}{*}{ LV — Limit Value } & quartz & $\begin{array}{l}\text { respirable } \\
\text { total dust }\end{array}$ & $\begin{array}{l}0.1 \\
0.3\end{array}$ & - & $\begin{array}{l}\mathrm{K} \\
\text { no }\end{array}$ & 1988 & 21,30 \\
\hline & & & $\begin{array}{l}\text { cristobalite } \\
\text { tridymite }\end{array}$ & $\begin{array}{l}\text { respirable, } \\
\text { total dust }\end{array}$ & $\begin{array}{l}0.05 \\
0.15\end{array}$ & - & $\begin{array}{l}\mathrm{K} \\
\text { no }\end{array}$ & & \\
\hline 13 & Estonia & $\begin{array}{l}\text { Piirnormid } \\
\text { (TWA-8h) }\end{array}$ & $\begin{array}{l}\text { quartz } \\
\text { cristobalite } \\
\text { tridymite }\end{array}$ & $\begin{array}{l}\text { respirable } \\
\text { respirable }\end{array}$ & $\begin{array}{c}0.1 \\
0.05\end{array}$ & - & no & 1998 & 31 \\
\hline 14 & Finland & $\begin{array}{l}\text { HTP - Haitalliseksi } \\
\text { Tunnetut Pitoisuudet } \\
\text { (TWA-8h) }\end{array}$ & $\begin{array}{l}\text { quartz } \\
\text { cristobalite } \\
\text { tridymite }\end{array}$ & $\begin{array}{l}\text { respirable } \\
\text { respirable }\end{array}$ & $\begin{array}{l}0.2 \\
0.1\end{array}$ & - & nd & 1993 & 21,32 \\
\hline 15 & France & $\begin{array}{l}\text { VME - Valeur } \\
\text { Limite de Moyenne } \\
\text { d'Exposition } \\
\text { (TWA-8h, 40-h } \\
\text { week) }\end{array}$ & $\begin{array}{l}\text { quartz } \\
\text { cristobalite, } \\
\text { tridymite }\end{array}$ & $\begin{array}{l}\text { respirable } \\
\text { respirable }\end{array}$ & $\begin{array}{c}0.1 \\
0.05\end{array}$ & - & no & 1997 & 33 \\
\hline 16 & Germany & $\begin{array}{l}\text { MAK - Maximale } \\
\text { Arbeitsplatzkon- } \\
\text { zentrationen }\end{array}$ & $\begin{array}{l}\text { quartz } \\
\text { cristobalite } \\
\text { tridymite }\end{array}$ & \multicolumn{3}{|c|}{$\begin{array}{l}\text { no standard - employers are obliged } \\
\text { to minimize exposure }\end{array}$} & MAK-1 & nd & 18,29 \\
\hline 17 & $\begin{array}{l}\text { Great } \\
\text { Britain }\end{array}$ & $\begin{array}{l}\text { WEL - Workplace } \\
\text { Exposure Limit } \\
\text { (TWA-8h) }\end{array}$ & $\begin{array}{l}\text { crystalline } \\
\text { silica }\end{array}$ & respirable & 0.1 & - & no & 2006 & 34 \\
\hline 18 & Greece & $\begin{array}{l}\text { OEL- } \\
\text { Occupational } \\
\text { Exposure Limit }\end{array}$ & $\begin{array}{l}\text { quartz } \\
\text { cristobalite, } \\
\text { tridymite }\end{array}$ & $\begin{array}{l}\text { respirable } \\
\text { respirable }\end{array}$ & $\begin{array}{c}0.1 \\
0.05\end{array}$ & - & nd & nd & 29 \\
\hline 19 & Hungary & $\begin{array}{l}\text { Megengedett } \\
\text { koncentráció }\end{array}$ & $\begin{array}{l}\text { quartz } \\
\text { cristobalite } \\
\text { tridymite } \\
\text { quartz }\end{array}$ & total dust & 0.1 & - & nd & 2000 & 36 \\
\hline 20 & India & $\begin{array}{l}\text { PLE - Permissible } \\
\text { Limit } \\
\text { of Exnosure }\end{array}$ & $\begin{array}{l}\text { dust } \\
\text { containing } \\
\text { free silica }\end{array}$ & respirable & $\frac{10}{\% \text { quartz }+2}$ & $0.03-0.1$ & nd & 1987 & 37 \\
\hline & & of Exposure & free silica & total dust & $\frac{30}{\% \text { quartz }+3}$ & $0.075-0.3$ & & & \\
\hline
\end{tabular}


Table 1. Occupational exposure limits for free crystalline silica - cont.

\begin{tabular}{|c|c|c|c|c|c|c|c|c|c|}
\hline \multirow[b]{2}{*}{ No. } & \multirow[b]{2}{*}{$\begin{array}{l}\text { Organiza- } \\
\text { tion/ } \\
\text { country }\end{array}$} & \multicolumn{7}{|c|}{ Limit values } & \multirow[b]{2}{*}{$\begin{array}{l}\text { Informa- } \\
\text { tion sourc }\end{array}$} \\
\hline & & $\begin{array}{l}\text { Exposure limit and } \\
\text { interpretation }\end{array}$ & $\begin{array}{l}\text { Crystalline silica } \\
\text { form }\end{array}$ & $\begin{array}{c}\text { Dust } \\
\text { fraction }\end{array}$ & $\begin{array}{l}\text { Limit value } \\
{\left[\mathrm{mg} / \mathrm{m}^{3}\right]}\end{array}$ & $\begin{array}{c}\text { Value } \\
\text { range } \\
\text { in refer- } \\
\text { ence } \\
\text { to } 100 \% \\
\mathrm{SiO}_{2}\end{array}$ & $\begin{array}{l}\text { Carcino- } \\
\text { genicity } \\
\text { remarks }\end{array}$ & $\begin{array}{l}\text { Year of } \\
\text { introduc- } \\
\text { tion } \\
\text { /publica- } \\
\text { tion }\end{array}$ & \\
\hline 21 & Ireland & $\begin{array}{l}\text { OEL_- Occupa- } \\
\text { tional Exposure } \\
\text { Limit }\end{array}$ & $\begin{array}{l}\text { quartz } \\
\text { cristobalite, } \\
\text { tridymite }\end{array}$ & respirable & 0.05 & - & nd & nd & 29 \\
\hline 22 & Italy & $\begin{array}{l}\text { TLV - Threshold } \\
\text { Limit Value }\end{array}$ & $\begin{array}{l}\text { quartz } \\
\text { cristobalite, } \\
\text { tridymite }\end{array}$ & respirable & 0.05 & - & nd & nd & 29 \\
\hline \multirow[t]{3}{*}{23} & Japan & $\begin{array}{l}\text { OEL-C-Occu- } \\
\text { pational Exposure } \\
\text { Limit Ceiling }\end{array}$ & $\begin{array}{l}\text { crystalline } \\
\text { silica }\end{array}$ & respirable & 0.03 & - & group 1 & 2006 & 38 \\
\hline & & OEL - Occupa- & dusts $<10 \%$ & respirable & 1 & $0.01-0.1$ & - & & \\
\hline & & $\begin{array}{l}\text { tional Exposure } \\
\text { Limit }\end{array}$ & of free silica & total dust & 4 & $0.04-0.4$ & - & & \\
\hline \multirow[t]{3}{*}{24} & Lithuania & $\begin{array}{l}\text { AER - Aroda } \\
\text { Ekkspozicijas }\end{array}$ & $\begin{array}{l}\text { dusts }>70 \% \text { of } \\
\text { crystalline } \mathrm{SiO}_{2}\end{array}$ & total dust & 1 & $0.7-1.0$ & nd & nd & 39 \\
\hline & & $\begin{array}{l}\text { robežverertïba } \\
\text { (TWA-8h, 40-h } \\
\text { week) }\end{array}$ & $\begin{array}{l}\text { dusts from } 10 \% \\
\text { to } 70 \% \text { of crys- } \\
\text { talline } \mathrm{SiO}_{2}\end{array}$ & & 2 & $0.2-1.4$ & & & \\
\hline & & & $\begin{array}{l}\text { dusts from } 2 \% \\
\text { to } 10 \% \text { of crys- } \\
\text { talline } \mathrm{SiO}_{2}\end{array}$ & & 4 & $0.08-0.4$ & & & \\
\hline 25 & \multicolumn{2}{|c|}{ Luxemburg Valeur Limite } & $\begin{array}{l}\text { quartz } \\
\text { cristobalite } \\
\text { tridymite }\end{array}$ & respirable & 0.15 & - & nd & nd & 29 \\
\hline 26 & Mexico & $\begin{array}{l}\text { OEL-Occupa- } \\
\text { tional Exposure } \\
\text { Limit (TWA) }\end{array}$ & $\begin{array}{l}\text { quartz } \\
\text { cristobalite, } \\
\text { tridymite }\end{array}$ & $\begin{array}{l}\text { respirable } \\
\text { respirable }\end{array}$ & $\begin{array}{c}0.1 \\
0.05\end{array}$ & - & nd & 2004 & $40,41,42$ \\
\hline \multirow[t]{2}{*}{27} & \multirow{2}{*}{$\begin{array}{l}\text { New } \\
\text { Zealand }\end{array}$} & \multirow{2}{*}{$\begin{array}{l}\text { Workplace Expo- } \\
\text { sure Standard } \\
\text { (TWA-8h) }\end{array}$} & quartz & respirable & 0.2 & - & $\mathrm{A} 2$ & 2002 & 43 \\
\hline & & & $\begin{array}{l}\text { cristobalite, } \\
\text { tridymite }\end{array}$ & respirable & 0.1 & & & & \\
\hline \multirow[t]{4}{*}{28} & \multirow[t]{4}{*}{ Norway } & \multirow{4}{*}{$\begin{array}{l}\text { OEL_- Occupa- } \\
\text { tional Exposure } \\
\text { Limit (TWA) }\end{array}$} & $\alpha$-quartz & respirable & 0.1 & - & K & 1994 & 21,44 \\
\hline & & & & total dust & 0.3 & & & & \\
\hline & & & cristobalite & respirable & 0.05 & & & & \\
\hline & & & tridymite & total dust & 0.15 & & & & \\
\hline 29 & Portugal & $\begin{array}{l}\text { OEL_- Occupa- } \\
\text { tional Exposure } \\
\text { Limit }\end{array}$ & $\begin{array}{l}\text { quartz } \\
\text { cristobalite, } \\
\text { tridymite }\end{array}$ & respirable & 0.05 & - & nd & nd & 29 \\
\hline \multirow[t]{2}{*}{30} & RPA: & & & & & & & & \\
\hline & $\begin{array}{l}\text { DOL } \\
\text { (Depart- } \\
\text { ment of } \\
\text { Labour) }\end{array}$ & $\begin{array}{l}\text { OEL-CL_- Occu- } \\
\text { pational Exposure } \\
\text { Limit - control } \\
\text { limit (TWA) }\end{array}$ & quartz & respirable & 0.4 & - & no & 1995 & 45 \\
\hline
\end{tabular}


Table 1. Occupational exposure limits for free crystalline silica — cont.

\begin{tabular}{|c|c|c|c|c|c|c|c|c|c|}
\hline \multirow[b]{2}{*}{ No. } & \multirow[b]{2}{*}{$\begin{array}{l}\text { Organiza- } \\
\text { tion/ } \\
\text { country }\end{array}$} & \multicolumn{7}{|c|}{ Limit values } & \multirow[b]{2}{*}{$\begin{array}{l}\text { Informa- } \\
\text { tion source }\end{array}$} \\
\hline & & $\begin{array}{l}\text { Exposure limit and } \\
\text { interpretation }\end{array}$ & $\begin{array}{l}\text { Crystalline silica } \\
\text { form }\end{array}$ & $\begin{array}{l}\text { Dust } \\
\text { fraction }\end{array}$ & $\begin{array}{l}\text { Limit value } \\
{\left[\mathrm{mg} / \mathrm{m}^{3}\right]}\end{array}$ & $\begin{array}{l}\text { Value } \\
\text { range } \\
\text { in refer- } \\
\text { ence } \\
\text { to } 100 \% \\
\mathrm{SiO}_{2}\end{array}$ & $\begin{array}{l}\text { Carcino- } \\
\text { genicity } \\
\text { remarks }\end{array}$ & $\begin{array}{l}\text { Year of } \\
\text { introduc- } \\
\text { tion } \\
\text { /publica- } \\
\text { tion }\end{array}$ & \\
\hline & $\begin{array}{l}\text { DME } \\
\text { (Depart- } \\
\text { ment of } \\
\text { Minerals } \\
\text { and En- } \\
\text { ergy) }\end{array}$ & $\begin{array}{l}\text { OEL - Occupa- } \\
\text { tional Exposure } \\
\text { Limit }\end{array}$ & $\begin{array}{l}\text { quartz } \\
\text { cristobalite } \\
\text { tridymite }\end{array}$ & respirable & 0.1 & - & no & 2002 & \\
\hline \multirow[t]{3}{*}{31} & Russia & $\begin{array}{l}\text { OEL - Occupa- } \\
\text { tional Exposure } \\
\text { Limit - TWA }\end{array}$ & quartz & total dust & 1 & - & nd & 2003 & 40,41 \\
\hline & & $\begin{array}{l}\text { STEL - Short- } \\
\text { Term Exposure Limit }\end{array}$ & & & 3 & & & & \\
\hline & & $\begin{array}{l}\text { STEL - Short- } \\
\text { Term Exposure Limit }\end{array}$ & cristobalite & total dust & 1 & & & & \\
\hline 32 & Slovakia & $\begin{array}{l}\text { NPHV — Najvy̌̌šie } \\
\text { Pripustné Hodnoty } \\
\text { Vystavenia }\end{array}$ & $\begin{array}{l}\text { quartz } \\
\text { cristobalite } \\
\text { tridymite }\end{array}$ & respirable & 0.1 & - & quartz: Cc & 2002 & 46 \\
\hline 33 & Slovenia & $\begin{array}{l}\text { OEL - Occupa- } \\
\text { tional Exposure } \\
\text { Limit }\end{array}$ & $\begin{array}{l}\text { quartz } \\
\text { cristobalite } \\
\text { tridymite }\end{array}$ & respirable & 0.15 & - & nd & nd & 29 \\
\hline 34 & Spain & $\begin{array}{l}\text { VLA-ED - Valore } \\
\text { Limite Ambient- } \\
\text { ales-Exposición } \\
\text { Diaria (TWA-8h; } \\
\text { 40-h week) }\end{array}$ & $\begin{array}{l}\text { quartz } \\
\text { cristobalite } \\
\text { tridymite }\end{array}$ & $\begin{array}{l}\text { respirable } \\
\text { respirable }\end{array}$ & $\begin{array}{c}0.1 \\
0.05\end{array}$ & - & no & 2003 & 47 \\
\hline 35 & Sweden & $\begin{array}{l}\text { NGV — Nivågrän- } \\
\text { svärde } \\
\text { (TWA-8h) }\end{array}$ & $\begin{array}{l}\text { quartz } \\
\text { cristobalite } \\
\text { tridymite }\end{array}$ & $\begin{array}{l}\text { respirable } \\
\text { respirable }\end{array}$ & $\begin{array}{c}0.1 \\
0.05\end{array}$ & - & no & 1996 & 48 \\
\hline 36 & $\begin{array}{l}\text { Switzer- } \\
\text { land }\end{array}$ & $\begin{array}{l}\text { VME - Valeur } \\
\text { Limite de Moyenne } \\
\text { d'Exposition } \\
\text { (TWA-8h, 42-h } \\
\text { week) }\end{array}$ & $\begin{array}{l}\text { quartz } \\
\text { cristobalite } \\
\text { tridymite }\end{array}$ & respirable & 0.15 & - & $\mathrm{Cc}$ & nd & 49 \\
\hline 36 & Thailand & TWA & $\begin{array}{l}\text { quartz } \\
\text { cristobalite } \\
\text { tridymite } \\
\text { quartz }\end{array}$ & total dust & 30 & - & nd & 1993 & $40,41,42$ \\
\hline 38 & $\begin{array}{l}\text { The } \\
\text { Nether- } \\
\text { landes }\end{array}$ & $\begin{array}{l}\text { MAC - Maximaal } \\
\text { Aanvaarde Concen- } \\
\text { traties (TWA-8h) }\end{array}$ & $\begin{array}{l}\text { quartz } \\
\text { cristobalite } \\
\text { tridymite }\end{array}$ & respirable & 0.075 & - & $\mathrm{Cc}$ & 1996 & 35 \\
\hline
\end{tabular}


Table 1. Occupational exposure limits for free crystalline silica - cont.

\begin{tabular}{|c|c|c|c|c|c|c|c|c|c|}
\hline \multirow[b]{2}{*}{ No. } & \multirow[b]{2}{*}{$\begin{array}{l}\text { Organiza- } \\
\text { tion/ } \\
\text { country }\end{array}$} & \multicolumn{7}{|c|}{ Limit values } & \multirow[b]{2}{*}{$\begin{array}{l}\text { Informa- } \\
\text { tion source }\end{array}$} \\
\hline & & $\begin{array}{l}\text { Exposure limit and } \\
\text { interpretation }\end{array}$ & $\begin{array}{l}\text { Crystalline silica } \\
\text { form }\end{array}$ & $\begin{array}{c}\text { Dust } \\
\text { fraction }\end{array}$ & $\begin{array}{l}\text { Limit value } \\
{\left[\mathrm{mg} / \mathrm{m}^{3}\right]}\end{array}$ & $\begin{array}{l}\text { Value } \\
\text { range } \\
\text { in refer- } \\
\text { ence } \\
\text { to } 100 \% \\
\mathrm{SiO}_{2}\end{array}$ & $\begin{array}{l}\text { Carcino- } \\
\text { genicity } \\
\text { remarks }\end{array}$ & $\begin{array}{l}\text { Year of } \\
\text { introduc- } \\
\text { tion } \\
\text { /publica- } \\
\text { tion }\end{array}$ & \\
\hline \multirow[t]{16}{*}{39} & $\begin{array}{l}\text { United } \\
\text { States }\end{array}$ & & & & & & & & \\
\hline & \multirow[t]{6}{*}{ OSHA } & \multirow{6}{*}{$\begin{array}{l}\text { PEL - Permis- } \\
\text { sible Exposure } \\
\text { Limit (TWA-8h, } \\
\text { 40-h week) }\end{array}$} & \multirow{2}{*}{\multicolumn{2}{|c|}{$\begin{array}{l}\text { dust containing respirable } \\
\text { quartz }\end{array}$}} & $10 \mathrm{mg} / \mathrm{m}^{3}$ & \multirow[t]{2}{*}{$0.03-0.1$} & \multirow[t]{4}{*}{ no } & \multirow[t]{4}{*}{1971} & \multirow[t]{6}{*}{21,50} \\
\hline & & & & & $\% \mathrm{SiO}_{2}+2$ & & & & \\
\hline & & & & total dust & $30 \mathrm{mg} / \mathrm{m}^{3}$ & $0.09-0.3$ & & & \\
\hline & & & & & $\% \mathrm{SiO}_{2}+2$ & & & & \\
\hline & & & \multirow{2}{*}{$\begin{array}{l}\text { dust containing } \\
\text { cristobalite, } \\
\text { tridymite }\end{array}$} & respirable & $\begin{array}{l}1 / 2 \text { of the value } \\
\text { for quartz }\end{array}$ & $0.015-0.05$ & \multirow[t]{2}{*}{ no } & \multirow[t]{2}{*}{1978} & \\
\hline & & & & total dust & $\begin{array}{l}1 / 2 \text { of the value } \\
\text { for quartz }\end{array}$ & $0.045-0.15$ & & & \\
\hline & \multirow[t]{3}{*}{ California } & \multirow{3}{*}{$\begin{array}{l}\text { PEL_- Permis- } \\
\text { sible Exposure } \\
\text { Limit }\end{array}$} & \multirow[t]{2}{*}{ quartz } & respirable & 0.1 & \multirow[t]{3}{*}{-} & \multirow[t]{3}{*}{ no } & \multirow[t]{3}{*}{ nd } & \multirow[t]{3}{*}{51} \\
\hline & & & & total dust & 0.3 & & & & \\
\hline & & & $\begin{array}{l}\text { cristobalite, } \\
\text { tridymite }\end{array}$ & respirable & 0.05 & & & & \\
\hline & Michigan & $\begin{array}{l}\text { EL_Exposure } \\
\text { Limit } \\
\text { (TWA-8h, 40-h } \\
\text { week) }\end{array}$ & $\begin{array}{l}\text { quartz } \\
\text { cristobalite, } \\
\text { tridymite }\end{array}$ & $\begin{array}{l}\text { respirable } \\
\text { respirable }\end{array}$ & $\begin{array}{c}0.1 \\
0.05\end{array}$ & - & no & nd & 52 \\
\hline & Minnesota & $\begin{array}{l}\text { PEL - Permis- } \\
\text { sible Exposure } \\
\text { Limit (TWA-8h) }\end{array}$ & $\begin{array}{l}\text { quartz } \\
\text { cristobalite, } \\
\text { tridymite }\end{array}$ & $\begin{array}{l}\text { respirable } \\
\text { respirable }\end{array}$ & $\begin{array}{c}0.1 \\
0.05\end{array}$ & - & no & nd & 53 \\
\hline & \multirow[t]{4}{*}{ Washington } & $\begin{array}{l}\text { PEL - Permis- } \\
\text { sible Exposure } \\
\text { Limit (TWA-8h) }\end{array}$ & quartz & respirable & 0.1 & \multirow[t]{4}{*}{-} & \multirow[t]{4}{*}{ no } & \multirow[t]{4}{*}{ nd } & \multirow[t]{4}{*}{54} \\
\hline & & STEL & & respirable & 0.3 & & & & \\
\hline & & $\begin{array}{l}\text { PEL_- Permis- } \\
\text { sible Exposure Limit } \\
\text { (TWA-8h) }\end{array}$ & $\begin{array}{l}\text { cristobalite } \\
\text { tridymite }\end{array}$ & respirable & 0.05 & & & & \\
\hline & & STEL & & respirable & 0.15 & & & & \\
\hline 40 & Poland & NDS — Najwyższe & dusts with & respirable & 0.3 & $0.15-0.3$ & no & 1985 & 55,56 \\
\hline & & $\begin{array}{l}\text { Dopuszczalne } \\
\text { Stężenie } \\
\text { (TWA-8h) }\end{array}$ & $\begin{array}{l}>50 \% \text { free } \\
\text { (crystalline) } \\
\text { silica content }\end{array}$ & total dust & 2 & $1.0-2.0$ & no & 1959 & 56,57 \\
\hline & & $\begin{array}{l}{[\mathrm{MAC}-} \\
\text { Maximum Allow- }\end{array}$ & dusts with $2 \%$ & respirable & 1 & $0.02-0.5$ & no & 1985 & 55,56 \\
\hline & & able Concentration] & $\begin{array}{l}\text { to } 50 \% \text { free } \\
\text { (crystalline) } \\
\text { silica content }\end{array}$ & total dust & 4 & $0.08-2.0$ & no & 1976 & 56,58 \\
\hline
\end{tabular}

A2; C2 — suspected human carcinogen $\mathrm{Ca}(\mathrm{NIOSH})$ - potential occupational carcinogen. K; Cc; group 1; MAK-1 — carcinogenic agent. nd — no data available. 
In Japan, OEL-C is interpreted as a maximum recommended value of the concentration measured within 5 minutes (or a shorter period of time). It has been binding since 2006 and is the only standard for respirable crystalline silica dust, except for the limit concerning the concentration of silica dust containing less than $10 \%$ of crystalline silica. Apart from Japan, the short-term exposure values have also been adopted by Russia and the state of Washington.

Most of the countries have introduced one standard value for all types of crystalline silica. However, in several countries which defined their standards in 1990s (e.g. Belgium, Chile, Denmark, Estonia, Finland, France, Greece, Spain, Canada, Mexico, Norway, the USA and Sweden) the values for quartz, cristobalite and tridymite have been considered separately. In these countries, the limit concentrations for cristobalite and tridymite are $50 \%$ as low as for quartz exposure.

In 2006, ACGIH, while defining the basics and directions of changes in the research-based setting of hygienic standards, decided to adopt the value of $0.025 \mathrm{mg} / \mathrm{m}^{3}$ as the exposure limit for respirable crystalline silica that would protect almost all the exposed workers against lung fibrosis that can be a risk factor of cancer [17]. Moreover, since the results of epidemiological studies did not reveal significant differences between exposure to various polymorphs of crystalline $\mathrm{SiO}_{2}$ and the development of lung fibrosis, the same standard was adopted also for $\alpha$-quartz and cristobalite. One year earlier, in 2005, ACGIH had withdrawn the standards for tridymite due to the lack of sufficient data regarding its adverse effects in work environment [59]. NIOSH which has presented a more practical approach to the workers' health protection, in 1974 recommended a limit value of $0.05 \mathrm{mg} / \mathrm{m}^{3}$ for crystalline silica. This value was established taking into account the technical capacity of the equipment used for the collection of air samples, and the detection limits of the analytical methods used for quantitative determinations of silica [4]. In the European Union, the Scientific Committee on Occupational Exposure Limits (SCOEL) has been working for several years on its own lists of indicative limit values for occupational exposure. In addition to this, appropriate directives of the European Commission make it obligatory for the Member States to define national limit values based on the EU value. However, the lists of hygienic standards published so far, that include about 90 chemical substances, have not contained any standards for crystalline silica [12-14]. The standard values for respirable crystalline silica adopted by most of the countries do not exceed the value of $0.1 \mathrm{mg} / \mathrm{m}^{3}$ (Argentina, Australia, Belgium, Bulgaria, Chile, the Czech Republic, Denmark, Estonia, France, Greece, Spain, India, Ireland, Canada, Mexico, Norway, Portugal, Slovakia, Sweden, the USA, Hungary, Great Britain and Italy). Some countries (Austria, Finland, Luxemburg, New Zealand, Slovenia and Switzerland) have adopted the limit value within the range of $0.15-0.2 \mathrm{mg} / \mathrm{m}^{3}$. Higher values for crystalline silica are binding in Poland, RPA (except for mining and energy industry) and Thailand. The highest concentration limits in Poland refer to dusts containing 2-50\% and 50-100\% free crystalline silica. For the $100 \%$ free crystalline silica, they range from 0.02 to $0.5 \mathrm{mg} / \mathrm{m}^{3}$. The commonly adopted limit value of $0.1 \mathrm{mg} / \mathrm{m}^{3}$ is binding only for exposure to dust containing from $2 \%$ to $10 \%$ of silica, with the exception of coal dust exposure. The highest MAC values for exposure to industrial dust, of $0.3-0.5 \mathrm{mg} / \mathrm{m}^{3}$, are those referring to dust with free crystalline silica content of 30-50\% that can be found in coal mines, quarries, building stone works, ceramic plants and many other worksites.

Lithuania and Russia have not established the standard values for respirable crystalline silica in work environment. However, the limit concentrations for total silica dust in these countries can be used as a basis for estimating the respirable fraction concentrations that can actually be encountered. The data for Poland, regarding exposure to dust containing free crystalline silica, that have been collected for several years, indicate that respirable dust concentrations are usually 4-5 times (less frequently 10 times) as low as the total dust concentrations (unpublished data). Thus, it can be assumed that in Lithuania, the limit value for respirable silica concentration, in 
exposure to dust containing 50-70\% free crystalline silica, would amount approximately to $0.35 \mathrm{mg} / \mathrm{m}^{3}$. In Russia, the value assessed in the same way would be lower and approximate $0.25 \mathrm{mg} / \mathrm{m}^{3}$.

As for Germany, no standard value has been established for crystalline silica since the chemical has been included in the list of category 1 carcinogens, and it is impossible to define a safety level for such substances. Consequently, no limit values are proposed and the employers are obliged to minimize exposure to such substances in work environment.

\section{Crystalline silica as a human carcinogen}

The carcinogenic potential of crystalline silica was already investigated in 1980s. In 1987, the Working Group of the International Agency for Research on Cancer (IARC), having analyzed evidence from animal experiments and the limited evidence for humans that indicated a potential carcinogenic effect of silica, amended the list of probable carcinogens with silica [60]. Ten years later, on the basis of further epidemiological studies (although non-homogeneous), IARC classified two crystalline forms of crystalline silica: quartz and cristobalite, to Group 1 human carcinogens [21]. The decision made by IARC did not eliminate the problem of the carcinogenic effect of silica. A review of recent epidemiological studies conducted in 1996-2005 among workers exposed to crystalline silica clearly indicates a relationship between lung cancer and the occurrence of silicosis. However, it is has not been elucidated whether silica may have had a carcinogenic effect on the exposed workers who did not develop the silicosis-like changes in the lung [61].

Apart from IARC, the lists of occupational carcinogens have been developed by prestigious American organizations such as ACGIH, NIOSH, and the National Toxicology Program (NTP), as well as by the European Union and some national organizations including Commission for the Investigation of Health Hazards of Chemical Compounds in the Work Area, of the German Research Foundation. The documents published by ACGIH, classified quartz and cristobalite into Group A2, of suspected human carcinogens [18]. NIOSH and NTP considered the three basic forms of crystalline silica: quartz, cristobalite and tridymite, as occupational carcinogens and human carcinogens, respectively [18]. Likewise, in Germany, these silica forms are classified as category 1 carcinogens, i.e. the substances known to cause cancer in humans or considered to increase the risk of cancer development [18]. The European Union has developed a list of chemical substances known to be carcinogenic to man (category 1); substances which should be regarded as if they are carcinogenic to man (category 2); and substances which cause concern for man owing to possible carcinogenic effects, but in respect of which the available information is not adequate for making a satisfactory assessment (category 3 ). The list was published in 1967 in Appendix 1 to the Council Directive 67/548/EEC [62]. Since its first publication, the list has been amended several times, including up to 29 Adapting to Technical Progress (ATP) documents [63]. However, crystalline silica was not listed under any of the abovementioned categories.

The registers of occupational hazards with their respective limit values usually include a note on carcinogenicity. Information about the carcinogenic effect of crystalline silica can be found in the lists of hygienic standards binding in Denmark [30], Netherlands [35], Switzerland [49], Slovakia [46], Norway [44] and Japan [38]. In Argentina [19], Canada, in the provinces of Quebec and British Columbia [25,27], and in New Zealand [43], silica has been claimed to be a probably carcinogenic agent. However, in many countries silica is not classified as a carcinogen; this referring to Austria [21], Belgium [23], France [33], Great Britain [34], Spain [47], Sweden [48], Estonia [31], Bulgaria [24], Australia [20], Chile [28] and the USA OSHA document [50] and internal regulations of several states [51-54]. In Poland, the Regulation of the Minister of Health and Social Welfare issued in 1996 [64] classified crystalline silica as an agent probably carcinogenic to humans. This Regulation had been in force until 30 March 2005. The new Regulation of the Minister of Health did not include silica among the substances and preparations with a carcinogenic or mutagenic effect under conditions of occupational exposure [65]. 


\section{FIELD MEASUREMENTS AND THE TESTS CONDUCTED TO COMPARE MEASUREMENT RESULTS WITH OCCUPATIONAL EXPOSURE LIMITS}

A substantial part of the assessment of occupational exposure to a given hazard are the measurements and tests used to evaluate whether the hygienic conditions in workplace and exposure level exceed respective standards. These measurements and tests are systematically repeated as a part of the workplace supervision system. In the case of dust exposure including exposure to crystalline silica, the guidelines on the performance of these tests are included in a number of international and European standards that are also binding in Poland. These standards regulate the following issues:

- definitions of terms related to air quality in general and to workplace air quality: PN-ISO 4225:1999 [66] with its Polish supplement PN-ISO 4225/Ak:1999 [67], and PN-EN 1540:2004 [68];

— guidelines on exposure assessment: PN-EN 689:2002 [11];

- characteristics of particle size of fractions for airborne dust measurement: PN-EN 481:1998 [69], PN-ISO 7708:2001 [70];

- technical requirements for equipment used in personal sampling, and evaluation criteria for performance of these instruments: PN-EN 1232:2002 [71], PN-EN 13205:2004 [72];

- general requirements for assessment procedures: PNEN 482:2002 [73].

The recommendations of the PN-EN 689:2002 standard [11] are general in character and are usually supplemented by guidelines adopted at the national level. In Poland, detailed regulations on the measurements and the tests carried out to compare the measurement results with the limit values, as well as on the calculation of exposure indices and interpretation of results, are included in the PN-Z-04008-7:2002 standard [74]. On the other hand, the mode, methods, and frequency of the measurements and tests are specified in the Regulation of the Minister of Health of 20 April 2005 [75].
As for the assessment of exposure to crystalline silica, the range of the measurements and tests depends on the way the hygienic standard is expressed. In Poland and in other countries in which the limit value for crystalline silica, as a concentration range, has been defined as the maximum concentration level of respirable dust and/or total dust, the exposure indices are average dust concentrations for a standard 8-hour work day/shift. The result of the analysis of free crystalline silica is used solely to select appropriate hygienic standard. Most frequently, when the limit value is given in milligrams of respirable crystalline silica dust in $1 \mathrm{~m}^{3}$ of air, dust concentration is insignificant for the assessment of exposure. What is important is the crystalline silica mass in the air samples.

The collection of air samples and determination of crystalline silica are the necessary steps in exposure assessment, regardless of the way the limit value is expressed.

\section{Air sampling}

The principles of air sample collection and concentration measurements of dust particles of different size are usually published as the methods or standards. The methods most commonly used worldwide and approved by the EU Member States for measuring and analyzing dust content in workplace atmosphere [76-78] are as follows:

- MDHS 14/3 [79] developed by HSL, Great Britain,

— NIOSH 0600 [80] and NIOSH 0500 [81] published by NIOSH, USA,

- OSHA PV2121 [82] from OSHA, USA,

- MetroPol Fiche 002 [83] and MetroPol Fiche 085 [84] from INRS, France,

— BIA 6068 [77] and BIA 7284 [78] from Germany,

- MTA/MA-014/A88 [85] from INSHT, Spain.

The methods specified above involve air sample collection by personal sampling in the worker's breathing zone, and gravimetric determination of dust concentration. The differences between these methods refer mainly to the fractions of respirable dust measured and their definitions, as well as the sampling pumps, pre-selectors and filters used, the nominal values of collected air samples and the validation results $[77,78]$. Most of these methods 
concern measurements of respirable dust. However, they do not define the notion of 'respirable dust' in the same way. In the European standard PN-EN 481:1998 [69] and in the international standard PN-ISO 7708:2001 [70], the size distribution of respirable dust is described by a cumulated log-normal distribution, with the median diameter of $4.25 \mu \mathrm{m}$ and geometric standard deviation of 1.5. The process of collecting air samples to isolate thus defined respirable dust is included in the MDHS 14/3 [79], MTA/ MA-014/A88 [85] and MetroPol Fiche 085 [84] methods. Respirable dust, isolated with the use of the OSHA PV2121 [82] and NIOSH 0600 [80] methods, is characterized by a slightly different size distribution of fractions. In the OSHA document [82], the median diameter is shifted towards smaller fractions and equals $3.5 \mu \mathrm{m}$, and in the NIOSH publication [80] it equals $4 \mu \mathrm{m}$.

The sampling and measurement procedures for the total dust are described in the following methods: MetroPol Fiche 002 [83], MTA/MA-014/A88 [85], NIOSH 0500 [81] and OSHA PV2121 [82]. Other methods, including MDHS 14/3 [79], MetroPol Fiche 085 [84] and BIA 7284 [78] refer to inhalable dust; however, both these terms are considered to be highly similar.

In Poland, the sampling and determination methods for total and respirable dust have been included in two standards: PN-91/Z-04030/06 [86] and PN-91/Z-04030/05 [87]. The procedures of individual dosimetry as described in these standards are generally similar to those pertaining to the European and American methods; however, the operation parameters for the pre-selector (cyclone) refer to only one kind of pre-selector. It is also possible to use other types of selectors, on condition that the air flow rate is adjusted so that the isolated dust fraction would comply with the definition of a respirable fraction as published in the Polish list of concentration limits for dusts. The definition of respirable dust in this document is the same as adopted by OSHA in the USA, i.e. the median diameter of dust particle is $3.5 \mu \mathrm{m}$, and the geometric standard deviation 1.5. The basic difference between the methods applied in Poland and those used worldwide is related to the approval of the static sampling. The main disadvantage of the static sampling is the uncertainty whether the collected samples are equivalent to actual exposure conditions of a given worker.

\section{Methods for determination of crystalline silica}

The methods for determining crystalline silica concentrations in workplace have so far been developed mainly in the USA, some European countries and Canada. In the European Union, a database called GESTIS Analytical Methods [76] was created in 2003, which comprises methods for the determination of hazardous substances in workplace. These are the methods used in different European countries and approved by 10 major research institutions in EU. In Poland, the Regulation of the Minister of Health of 20 April 2005 [75] approves the use of the methods that are concordant with the Polish or international standards. As regards workplace exposure to free crystalline silica, the determination methods have been specified in three Polish standards: PN-91/Z-04018/04 [88], PN-91/Z-04018/02 [89] and PN-91/Z-04018/03 [90]. In practice, over $90 \%$ of the state laboratories dealing with determinations in work environment use the same method of visible absorption spectrophotometry (a chemical method) according to the PN-91/Z-04018/04 standard [88].

Table 2 presents the methods of analyzing crystalline silica that are included in the GESTIS Analytical Methods database $[91,92]$ and the Polish standardized methods.

The current methods applied to the determination of free crystalline silica in workplace are based on three analytical techniques: X-ray diffraction (XRD), infrared spectrophotometry (FT-IR or IR), and visible absorption spectrophotometry (chemical methods). Two of these methods, namely XRD and IR, make it possible to separately determine the main forms of crystalline silica: quartz, cristobalite and tridymite. The visible absorption spectrophotometry is used to determine the total content of all crystalline forms of silica.

In the determinations, one of the most essential and difficult steps is sample preparation. Only a few of the methods enable direct determination of silica in the samples collected in workplace. The MDHS 101 method [93], ranked first in the GESTIS database [91,92], and the MétroPol Fiche 049 method [94] are the only methods of those presented 
Table 2. Methods for determination of crystalline silica approved by the EU for assessment of workplace exposure [91,92] [items 1-10], and Polish standardized methods [items 11-13]

\begin{tabular}{|c|c|c|c|c|c|c|}
\hline No. & Method & $\begin{array}{l}\text { Source - } \\
\text { institution, } \\
\text { country, } \\
\text { year of } \\
\text { publication }\end{array}$ & $\begin{array}{c}\text { Sampling procedure, } \\
\text { nominal air sample } \\
\text { volume }\end{array}$ & $\begin{array}{l}\text { Analytical technique, } \\
\text { sample preparation }\end{array}$ & $\begin{array}{l}\text { Reference } \\
\text { material }\end{array}$ & $\begin{array}{l}\text { LOD, LOQ, } \\
\text { analytical precision } \\
\text { (RSD) for quartz }\end{array}$ \\
\hline 1 & $\begin{array}{l}\text { MDHS } 101 \\
{[93]}\end{array}$ & $\begin{array}{l}\text { HSL, } \\
\text { Great } \\
\text { Britain, } \\
2005\end{array}$ & $\begin{array}{l}\text { respirable dust } \\
\text { collected on PVC } \\
\text { (FT-IR) or Ag filter } \\
\text { (XRD), according } \\
\text { to MDHS 14/3 [79], } \\
0.6 \mathrm{~m}^{3}\end{array}$ & $\begin{array}{l}\text { FT-IR and XRD, } \\
\text { sample analyzed directly } \\
\text { on filter }\end{array}$ & $\begin{array}{l}\text { quartz SRM } \\
1878 \text { (NIST), } \\
\text { Sikron F600 }\end{array}$ & $\begin{array}{l}\text { FT-IR: } \\
3 \mu \mathrm{g}, 0.02 \mathrm{mg} / \mathrm{m}^{3} \\
\text { XRD: } \\
10 \mu \mathrm{g}, 0.05 \mathrm{mg} / \mathrm{m}^{3} \\
\text { FT-IR, XRD: } \\
\text { RSD }=0.087\end{array}$ \\
\hline 2 & $\begin{array}{l}\text { MétroPol Fiche } \\
049 \\
{[94]}\end{array}$ & $\begin{array}{l}\text { INRS, } \\
\text { France, } \\
1999\end{array}$ & $\begin{array}{l}\text { respirable dust } \\
\text { collected on PVC } \\
\text { filter, after } \\
\text { Fiche } 002 \text { [83], } \\
0.6 \mathrm{~m}^{3}\end{array}$ & $\begin{array}{l}\text { XRD, } \\
\text { sample }<0.6 \mathrm{mg} / \mathrm{cm}^{2} \\
\text { analyzed directly on filter, } \\
\text { otherwise demineralized } \\
\text { and redeposited onto } \\
\text { a polycarbonate filter }\end{array}$ & $\begin{array}{l}\text { no data } \\
\text { available }\end{array}$ & LOQ: $0.05 \mathrm{mg} / \mathrm{m}^{3}$ \\
\hline 3 & $\begin{array}{l}\text { BIA } 8522 \\
{[91,92]}\end{array}$ & $\begin{array}{l}\text { Germany, } \\
1995\end{array}$ & $\begin{array}{l}\text { respirable dust } \\
\text { collected on MCE } \\
\text { filter, } 1 \mathrm{~m}^{3}\end{array}$ & $\begin{array}{l}\text { FT-IR, } \\
\text { sample demineralized, } \\
\text { preparation in a pellet } \\
\text { form with } \mathrm{KCl}\end{array}$ & $\begin{array}{l}\text { no data } \\
\text { available }\end{array}$ & LOQ: $0.035 \mathrm{mg} / \mathrm{m}^{3}$ \\
\hline 4 & $\begin{array}{l}\text { MTA/MA-036 } \\
{[95]}\end{array}$ & $\begin{array}{l}\text { INSHT, } \\
\text { Spain, } \\
2000\end{array}$ & $\begin{array}{l}\text { respirable dust } \\
\text { collected on PVC } \\
\text { filter, } 0.4 \mathrm{~m}^{3}\end{array}$ & $\begin{array}{l}\text { XRD, } \\
\text { sample demineralized and } \\
\text { redeposited onto PVC filter }\end{array}$ & $\begin{array}{l}\text { quartz SRM } \\
1878 \text { (NIST), } \\
\text { quartz BCR } 66^{2}\end{array}$ & $\begin{array}{l}7 \mu \mathrm{g}, 0.06 \mathrm{mg} / \mathrm{m}^{3} \\
\mathrm{RSD}=0.14 \\
\text { range } 20-200 \mu \mathrm{g}\end{array}$ \\
\hline 5 & $\begin{array}{l}\text { MTA/MA-057 } \\
{[96]}\end{array}$ & $\begin{array}{l}\text { INSHT, } \\
\text { Spain, } \\
2004\end{array}$ & $\begin{array}{l}\text { respirable dust } \\
\text { collected on PVC } \\
\text { filter according to } \\
\text { MTA/MA/-014/A88 } \\
{[85],} \\
\text { not defined }\end{array}$ & $\begin{array}{l}\text { FT-IR or IR, } \\
\text { sample demineralized, } \\
\text { preparation in a pellet } \\
\text { form with } \mathrm{KBr}\end{array}$ & $\begin{array}{l}\text { quartz SRM } \\
1878 \text { (NIST), } \\
\text { quartz BCR } 66^{2}, \\
\text { quartz } \\
\text { SARM } 49^{3}\end{array}$ & no data available \\
\hline 6 & $\begin{array}{l}\text { NIOSH } 7500 \\
{[97]}\end{array}$ & $\begin{array}{l}\text { NIOSH, } \\
\text { USA, } \\
2003\end{array}$ & $\begin{array}{l}\text { respirable dust } \\
\text { collected on PVC } \\
\text { filter, } 0.4 \mathrm{~m}^{3}\end{array}$ & $\begin{array}{l}\text { XRD, } \\
\text { sample demineralized or } \\
\text { dissolved in tetrahydrofuran } \\
\text { and redeposited onto } \\
\text { Ag filter }\end{array}$ & $\begin{array}{l}\text { quartz SRM } \\
1878 \text { (NIST), } \\
\text { cristobalite SRM } \\
1879 \text { (NIST), } \\
\text { tridymite }^{4}\end{array}$ & $\begin{array}{l}5 \mu \mathrm{g}, 0.025 \mathrm{mg} / \mathrm{m}^{3} \\
\mathrm{RSD}=0.08 \\
\text { range } 50-200 \mu \mathrm{g}\end{array}$ \\
\hline 7 & $\begin{array}{l}\text { NIOSH } 7601 \\
{[98]}\end{array}$ & $\begin{array}{l}\text { NIOSH, } \\
\text { USA, } \\
2003\end{array}$ & $\begin{array}{l}\text { respirable dust } \\
\text { collected on PVC } \\
\text { or MCE filter, } \\
0.4 \mathrm{~m}^{3}\end{array}$ & $\begin{array}{l}\text { visible absorption } \\
\text { spectrophotometry, } \\
\text { sample treated with } \mathrm{HNO}_{3} \text {, } \\
\text { silicate interferences removed } \\
\text { in } \mathrm{HClO}_{4} \text {, crystalline } \\
\mathrm{SiO}_{2} \text { dissolved in } \mathrm{HF} \text { and } \\
\text { determined as } \\
\text { silicomolybdenum blue }\end{array}$ & $\begin{array}{l}\text { quartz SRM } \\
1878 \text { (NIST), } \\
\text { cristobalite SRM } \\
1879 \text { (NIST), } \\
\text { tridymite }^{4}\end{array}$ & $\begin{array}{l}10 \mu \mathrm{g}, 0.05 \mathrm{mg} / \mathrm{m}^{3} \\
\mathrm{RSD}=0.09\end{array}$ \\
\hline 8 & $\begin{array}{l}\text { NIOSH } 7602 \\
\text { [99] }\end{array}$ & $\begin{array}{l}\text { NIOSH, } \\
\text { USA, } \\
2003\end{array}$ & $\begin{array}{l}\text { respirable dust } \\
\text { collected on PVC } \\
\text { filter, } 0.4 \mathrm{~m}^{3}\end{array}$ & $\begin{array}{l}\text { FT-IR or IR, } \\
\text { sample demineralized, } \\
\text { preparation in a pellet } \\
\text { form with } \mathrm{KBr}\end{array}$ & $\begin{array}{l}\text { quartz SRM } \\
1878 \text { (NIST), } \\
\text { cristobalite } \\
\text { SRM } 1879 \text { (NIST), } \\
\text { tridymite }^{4}\end{array}$ & $\begin{array}{l}5 \mu \mathrm{g}, 0.03 \mathrm{mg} / \mathrm{m}^{3} \\
\mathrm{RSD}<0.15 \\
\text { for } 30 \mu \mathrm{g}\end{array}$ \\
\hline
\end{tabular}


Table 2. Methods for determination of crystalline silica approved by the EU for assessment of workplace exposure [91,92] [items 1-10], and Polish standardized methods [items 11-13] — cont.

\begin{tabular}{|c|c|c|c|c|c|c|}
\hline No. & Method & $\begin{array}{l}\text { Source- } \\
\text { institution, } \\
\text { country, } \\
\text { year of } \\
\text { publication }\end{array}$ & $\begin{array}{c}\text { Sampling procedure, } \\
\text { nominal air sample } \\
\text { volume }\end{array}$ & $\begin{array}{l}\text { Analytical technique, } \\
\text { sample preparation }\end{array}$ & $\begin{array}{l}\text { Reference } \\
\text { material }\end{array}$ & $\begin{array}{l}\text { LOD, LOQ, } \\
\text { analytical precision } \\
\text { (RSD) for quartz }\end{array}$ \\
\hline 9 & $\begin{array}{l}\text { NIOSH } 7603 \\
{[100]}\end{array}$ & $\begin{array}{l}\text { NIOSH, } \\
\text { USA, } \\
2003\end{array}$ & $\begin{array}{l}\text { respirable coal dust } \\
\text { collected on PVC } \\
\text { filter, } 0.5 \mathrm{~m}^{3}\end{array}$ & $\begin{array}{l}\text { FT-IR or IR, } \\
\text { sample demineralized and } \\
\text { redeposited onto PVC- } \\
\text { acrylonitrile filter }\end{array}$ & $\begin{array}{l}\text { quartz SRM } \\
1878 \text { (NIST) }\end{array}$ & $\begin{array}{l}10 \mu \mathrm{g}, 0.065 \mathrm{mg} / \mathrm{m}^{3} \\
\mathrm{RSD}=0.098 \\
\text { range of } \\
100-500 \mu \mathrm{g}\end{array}$ \\
\hline 10 & $\begin{array}{l}\text { OSHA ID-142 } \\
{[101]}\end{array}$ & $\begin{array}{l}\text { OSHA, } \\
\text { USA, } \\
1996\end{array}$ & $\begin{array}{l}\text { respirable dust } \\
\text { collected on PVC } \\
\text { filter, } 0.8 \mathrm{~m}^{3}\end{array}$ & $\begin{array}{l}\mathrm{XRD} \\
\text { sample dissolved in } \\
\text { tetrahydrofuran and } \\
\text { redeposited onto Ag filter }\end{array}$ & $\begin{array}{l}\text { quartz SRM } \\
1878 \text { (NIST), } \\
\text { Min-U-Sil 55, } \\
\text { cristobalite } \\
\text { SRM } 1879 \text { (NIST) }\end{array}$ & $\begin{array}{l}5 \mu \mathrm{g}, 0.02 \mathrm{mg} / \mathrm{m}^{3} \\
\mathrm{RSD}=0.11 \\
\text { range of } 50-160 \mu \mathrm{g}\end{array}$ \\
\hline 11 & $\begin{array}{l}\text { PN-91/Z-04018/04 } \\
\text { [88] }\end{array}$ & $\begin{array}{l}\text { PKNMiJ, } \\
\text { Poland } \\
1991\end{array}$ & $\begin{array}{l}\text { total or respirable } \\
\text { dust collected on } \\
\text { FiPro }^{6} \text { or PVC filter, } \\
\text { according to PN- } \\
\text { 91/Z-04030/05 [86] } \\
\text { or PN-91/Z-04030/06 } \\
\text { [87] } 0.7 \mathrm{~m}^{3} \text { minimum } \\
\text { sample mass }-4 \mathrm{mg}\end{array}$ & $\begin{array}{l}\text { visible absorption } \\
\text { spectrophotometry, } \\
\text { sample ashed, intereferences } \\
\text { removed in } \mathrm{HCl} \text { and } \mathrm{HBF}_{4} \text {, } \\
\text { crystalline } \mathrm{SiO}_{2} \text { melted with } \\
\mathrm{NaHCO}_{3}+\mathrm{NaCl}_{\text {, and after }} \\
\text { dissolving and hydrolyzing } \\
\text { the mixture, determined } \\
\text { as silicomolibdenum blue }\end{array}$ & $\begin{array}{l}\text { no data } \\
\text { available }\end{array}$ & $\begin{array}{l}35 \mu \mathrm{g}, 0.10 \mathrm{mg} / \mathrm{m}^{3} \\
\mathrm{RSD}=0.10 \\
\text { (IOM data for } \\
\text { total dust) }\end{array}$ \\
\hline 12 & $\begin{array}{l}\text { PN-91/Z-04018/02 } \\
\text { [89] }\end{array}$ & $\begin{array}{l}\text { PKNMiJ, } \\
\text { Poland } \\
1991\end{array}$ & $\begin{array}{l}\text { total dust collected } \\
\text { on MCE or PVC } \\
\text { filter, according to } \\
\text { PN-91/Z-04030/05 } \\
{[86], 0.7 \mathrm{~m}^{3}} \\
\text { minimum sample } \\
\text { mass }-5 \mathrm{mg}\end{array}$ & $\begin{array}{l}\text { IR, } \\
\text { sample demineralized, } \\
\text { preparation in a pellet form } \\
\text { with } \mathrm{KBr}\end{array}$ & $\begin{array}{l}\text { description } \\
\text { method of } \\
\text { standard } \\
\text { quartz } \\
\text { preparation }\end{array}$ & $\begin{array}{l}\sim 20-25 \mu \mathrm{g} \\
0.07 \mathrm{mg} / \mathrm{m}^{3} \\
\text { RSD - no data } \\
\text { available }\end{array}$ \\
\hline 13 & $\begin{array}{l}\text { PN-91/Z-04018/03 } \\
{[90]}\end{array}$ & $\begin{array}{l}\text { PKNMiJ, } \\
\text { Poland } \\
1991\end{array}$ & $\begin{array}{l}\text { respirable dust } \\
\text { collected on MCE or } \\
\text { PVC filter, according } \\
\text { to PN-91/Z-04030/06 } \\
{[87], 0.7 \mathrm{~m}^{3}} \\
\text { minimum sample } \\
\text { mass }-5 \mathrm{mg}\end{array}$ & $\begin{array}{l}\text { IR, } \\
\text { sample demineralized, } \\
\text { preparation in a pellet form } \\
\text { with } \mathrm{KBr}\end{array}$ & $\begin{array}{l}\text { description } \\
\text { method of } \\
\text { standard } \\
\text { quartz } \\
\text { preparation }\end{array}$ & $\begin{array}{l}\sim 20-25 \mu \mathrm{g} \\
0.07 \mathrm{mg} / \mathrm{m}^{3} \\
\text { RSD - no data } \\
\text { available }\end{array}$ \\
\hline
\end{tabular}

\footnotetext{
${ }^{1}$ From HSL, Great Britain. ${ }^{2}$ From IRMM, Belgium. ${ }^{3}$ From South Africa Bureau of Standards, SAR. ${ }^{4}$ From U.S. Geological Survey, USA.
}

${ }^{5}$ From Pensylvania Glass Sand Co., USA. ${ }^{6}$ Polypropylene microfiber filter.

in Table 2 that do not require any treatment of dust collected on filter before the measurements employing diffraction and infrared spectrophotometry. In other methods, both the samples and the filters are mineralized or dissolved in tetrahydrofuran. Then, the filter deposits are redeposited onto other filters, as in the XRD technique, or they are mixed with potassium bromide or chloride to yield material to prepare pellets, as in IR spectrophotometry. The methods in the GESTIS database refer to the determination of free crystalline silica in respirable dust. The results of analyses are expressed in such a way that it is possible to directly compare the outcomes with the limit values adopted in most of the EU countries: in milligrams of crystalline silica in $1 \mathrm{~m}^{3}$ of air. The results of analyses 
conducted according to Polish standards, expressed as the percentage of silica content, are used only to select appropriate MAC values. Contrary to other analytical methods, this mode requires additional determination of the sample mass. In the determinations of total dust, the use of personal sampling for collecting samples with a required mass during an 8-hour working shift is disputable. It does not apply to the determinations of respirable dust fraction. In work environment, where dust concentrations reach the level of current MAC values [56], to obtain the sample mass recommended for visible absorption spectrophotometry [88], namely of $4 \mathrm{mg}$ respirable dust containing over $50 \%$ free crystalline silica, the sample should be collected individually over a period of 12 work shifts. In exposure to dust containing from $2 \%$ to $50 \%$ free crystalline silica, the sampling would have to last 3 work shifts. Likewise, the estimated sampling time for total dust with crystalline silica content of over $50 \%$ would be almost 2 work shifts. Thus, collecting a sample of proper mass during a single 8-h work shift is realistic only in exposure to total dust containing from $2 \%$ to $50 \%$ free crystalline silica. As it is practically unfeasible to conduct individual sampling during one work day, the method of stationary sample collection has been widely used; however, the results are less representative of the actual conditions of occupational exposure.

In determining free crystalline silica, the dusts isolated from workplace air usually contain many other substances that may have influence on the results of analysis. The dust components in question include feldspars, micas, kaolinite, clay minerals, graphite, large quantities of amorphous silica as well as other silicate and aluminosilicate minerals [93,96,97,99,101-104]. The fact that an analyzed sample contains a mixture of different silica forms is another disadvantage, making it difficult to determine the quantity of each component. The physical properties of these substances are so much alike that they hinder the determination. A variety of means and methods have been applied in different countries to overcome this problem. For instance, the methods based on visible absorption spectrophotometry involve removing these dust components as a part of the analytical procedure [88,98]. In XRD methods, the interference resulting from the overlapping diffraction peaks can be eliminated by analyzing the lines of less intensity that do not overlap with the lines of the other components of the sample. In IR spectrophotometry, the interference is limited by computerized development of the curves correcting their influence, e.g. by scaled subtraction of interferent spectra and forming higher-order derivative spectra $[93,96,99,100,102,106,107]$. Irrespective of the method used, it is possible to carry out a procedure of removing some sample components by ashing or chemically dissolving them, prior to the analytical measurements [96,99,102].

All the methods used for the determination of crystalline silica forms in work environment are comparative methods that require calibration with reference materials. The methods worked out by HSL, NIOSH, OSHA and INSHT recommend the use of certified reference materials of the highest quality that derive from NIST, US. These are respirable $\alpha$-quartz SRM 1878a and respirable cristobalite SRM 1879a. Other recommended reference materials include Sikron F600 (quartz A9950) from HSL, UK, and to a less extent BCR 66 from IRMM, Belgium, as well as the materials used in individual countries, for instance Min-U-Sil 5 in the USA. The Polish methods do not recommend any reference materials; the description of determinations employing infrared spectrophotometry contains a brief outline of preparing in-house standards. Another problem is the lack of certified reference material for analysis of crystalline silica in total dust.

The results of determinations of free crystalline silica, conducted using the same method but calibrated with different quartz standards as the reference materials, can differ significantly. The literature on this subject indicates that some quartz reference materials are characterized by a lower content of crystalline silica (from several to 30\%) as compared to quartz SRM 1878a from NIST that is usually used as the basis for comparisons [108-111]. Moreover, the reference materials differ in the distribution of particle size, which can also have influence on calibration results $[109,110]$.

Another source of the differences between determination results can be the way of preparing samples for analysis. In the studies by Kauffer et al. [112], the results obtained 
from direct on-filter determinations were several per cent higher than the results from the indirect methods. The authors explain the observed inconsistence in results by the elimination or conversion of some components, including interferents, during sample mineralization, and a higher probability of losing the substance analyzed during some additional analytical procedures. A comparison of the average results of determinations employing the XRD and IR techniques revealed a high consistence. The findings obtained when the XRD method was used were about $2 \%$ higher than the results from the IR method [112]. The inter-laboratory comparisons of determination results, such as WASP conducted by HSE, UK [113] and PAT by AIHA, USA [114], as well as the research conducted by Pickard at al. [115] proved that the average values of the results obtained using the XRD and IR methods, differ by several per cent maximally and can be considered comparable.

More substantial differences were noted while examining the influence of dust components on the results of determining free crystalline silica. The results yielded by the IR method were more likely to be affected by interferents than those obtained using the XRD method [114]. Moreover, WASP proficiency testing [113] revealed that the analyses conducted directly on the filters were more precise than the analyses employing an indirect method. The highest differences between the average results were observed in PAT proficiency testing [114], when the comparison concerned determination results from a chemical method congruent with NIOSH 7601 [98] and the IR and XRD methods. The chemical method provided results that differed by about $20 \%$ from those obtained via other methods, regardless of the crystalline silica content in the sample. The differences were higher for low silica content $(40-60 \mu \mathrm{g})$ and decreased in determinations with a substantial silica content exceeding $140 \mu \mathrm{g}$.

It is not possible to compare the determination results for crystalline silica as obtained from the methods used in Poland with those used abroad, due to the different fractions of dust analyzed. In Poland, free crystalline silica is determined mainly in total dust, while in other countries in respirable dust. Only one comparison [116] refers to the results of determination in total dust - the chemical method, congruent with the PN-91/Z-04018/04 standard [88], was compared with the IR method after NIOSH 7602 [99] modified with respect to sample preparation, and with the XRD method (internal standard). The comparisons revealed a high correlation coefficient $(r>0.99)$ between the results obtained from particular methods. However, the differences between the results varied from several $\%$ to $30 \%$, depending on the free crystalline silica content and the occurrence of interferents.

The methods for the determination of free crystalline silica in workplace that are recommended by the EU are the validated methods. Table 2 displays the operating parameters for the methods in relation to quartz: limits of detection, limits of quantification (calculated as the concentration of crystalline silica in air volume), and analytical precision. The data indicate that the IR methods are characterized by lower detection and quantification limits. However, evidence from literature implies that the methods have a lower selectivity, compared to XRD methods $[4,105,115]$. In most of the methods of the GESTIS database, the limits of quantification make it possible to determine crystalline silica at concentrations approaching the currently binding limit values. However, only a few of them: MDHS 101, NIOSH 7500 and OSHA ID-142, can be applied to analyzing free crystalline silica at the safety level defined for work environment. Another important validation parameter, namely the precision of the method, is similar for all the methods and ranges from $8 \%$ to $15 \%$. The analysis of results obtained from WASP proficiency testing for within-laboratory variability of determination results showed that the determinations employing the chemical method (congruent with NIOSH 7601 [98]) were significantly less precise [113]. Moreover, the direct methods were characterized by a lower variability of results, compared with the indirect methods.

\section{CONCLUSIONS}

The review of the legal regulations and analytical guidelines on the assessment of exposure to free crystalline silica made it possible to draw the following conclusions: 
1. It seems advisable to adopt the value of $0.05 \mathrm{mg} / \mathrm{m}^{3}$ as the maximum admissible concentration for respirable crystalline silica dust. The specified MAC value protects the exposed workers from developing silicosis and takes into account the technical capacity of the sampling apparatus and the specific measurement method used for the determinations of free crystalline silica.

2. An improvement of the methods for air sampling and determining crystalline silica concentrations, particularly at low concentration levels, is a major practical problem to be solved.

3. In Poland, the MAC values for crystalline silica, which have been binding unchanged for many years now, need to be verified and adapted to the present exposure conditions. It also seems necessary to implement the determination methods based on analytical techniques: Fourier Transform Infrared Spectrometry (FT-IR) and X-Ray Diffractometry (XRD).

\section{ABBREVIATIONS AND ACRONYMS}

ACGIH - American Conference of Governmental Industrial Hygienists

AIHA - American Industrial Hygiene Association

ATP - Adapting to Technical Progress

FT-IR - Fourier Transform Infrared Spectroscopy

HSE - Health and Safety Executive, UK

HSL - Health and Safety Laboratory, UK

IARC - International Agency for Research on Cancer

INRS - Institut National de Recherche et de Sécurité, France

INSHT - Instituto National de Seguridad e Higiene en el Trabajo, Spain

IR - infrared

IRMM - Institute for Reference Materials and Measurement

LOD - limit of detection

LOQ - limit of quantification

MCE - mixed cellulose esters

MDHS - methods for the determination of hazardous substances
NIOSH - National Institute for Occupational Safety and Health, USA

NIST - National Institute of Standards and Technology, USA

NTP - National Toxicology Program, USA

OSHA - Occupational Safety and Health Administration, USA

PKNMiJ — Polski Komitet Normalizacji, Miar i Jakości, Poland

PCV - polyvinyl chloride

RSD - relative standard deviation

SMR - standard reference materials

STEL - short-term exposure limit

TWA - time-weighted average

XRD - X-ray diffraction

\section{REFERENCES}

1. PN-91/Z-04018/01: Air purity protection. Tests for free crystalline silica. General aspects and scope of the standard Warszawa: Polski Komitet Normalizacji, Miar i Jakości; 1991 [in Polish].

2. Central Statistical Office: Statistical Yearbook of Industry 2006. Warszawa: Zakład Wydawnictw Statystycznych; 2006.

3. Marek K: Occupational respiratory diseases. In: Marek K, editor. Occupational diseases. Warszawa: Wydawnictwo Lekarskie PZWL; 2001. p. 30-158 [in Polish].

4. NIOSH Hazard Review: Health Effects of Occupational Exposure to Respirable Crystalline Silica. Cincinnati: U.S. National Institute for Occupational Safety and Health, Publication No. 2002-129; 2002.

5. Calvert GM, Rice FL, Boiano JM, Sheehy JW, Sanderson WT: Occupational silica exposure and risk of various diseases: an analysis using death certificates from 27 states of the United States. Occup Environ Med 2003;60:122-9.

6. Yassin A, Yebesi F, Tingle R: Occupational Exposure to Crystalline Silica Dust in the United States, 1988-2003. Environ Health Perspect 2005;113:255-60.

7. HSE information sheet. Construction Information Sheet No 36, Revision 1: Silica (cited 2007 April 20). Available at http://www.hse.gov.uk/pubns/cis36.pdf. 
8. European Commission. Millions of workers' health to be protected by Europe's first multisector agreement (cited 2007 June 11). Available at http://ec.europa.eu/employment_social/emplweb/news/news_en.cfm?id=152.

9. Vincent R, Jeandel B: COLCHIC - Occupational Exposure to Chemical Agents Database: Current Content and Development Perspectives. Appl Occup Environ Hyg 2001;16(2):115-21.

10. Stamm R: MEGA Database: One Million Data Since 1972. Appl Occup Environ Hyg 2001;16(2):159-63.

11. PN-EN 689:2002: Workplace atmospheres - Guidance for the assessment of exposure by inhalation to chemical agents for comparison with limit values and measurement strategy. Warszawa: Polish Committee for Standardization (PKN); 2002 [in Polish].

12. Commission Directive 91/322/EEC of 29 May 1991 on establishing indicative limit values by implementing Council Directive 80/1107/EEC on the protection of workers from the risks related to exposure to chemical, physical and biological agents at work.

13. Commission Directive 2000/39/EC of 8 June 2000 establishing a first list of indicative occupational exposure limit values in implementation of Council Directive 98/24/EC on the protection of the health and safety of workers from the risks related to chemical agents at work.

14. Commission Directive 2006/15/EC of 7 February 2006 establishing a second list of indicative occupational exposure limit values in implementation of Council Directive 98/24/EC and amending Directives 91/322/EEC and 2000/39/EC.

15. Brandys RC, Brandys GM: Global Occupational Exposure Limits for over 5000 Specific Chemicals. Occupational and Environmental Health Consulting Services Inc, Illinois 2006.

16. 2006 TLVs and BEIs Based on Documentation on the Threshold Limit Values for Chemical Substances and Physical Agents and Biological Exposure Indices. American Conference of Governmental Industrial Hygienists, Cincinnati 2006.

17. American Conference of Governmental Industrial Hygienists: Silica, Crystalline: $\alpha$-Quartz and Cristobalite. Documentation of TLVs and BEIs, Cincinnati 2006, CD-ROM.
18. 2006 Guide to Occupational Exposure Values. American Conference of Governmental Industrial Hygienists, Cincinnati 2006.

19. Resolución №295/2003 del Ministerio de Trabajo, Empleo y Seguridad Social B.O. 21/11/2003. Anexo III Correspondiente al articulo 61 de la reglamentacion (cited 2007 May 9). Available at http://infoleg.mecon.gov.ar/infolegInternet/anexos/30000-34999/32030/dto351-1979-anexo3.htm.

20. Australian Government. Australian Safety and Compensation Council. Hazardous Substances Information System (cited 2007 May 9). Available at http://hsis.ascc.gov.au/Default.aspx.

21. IARC Monographs on the Evaluation of Carcinogenic Risk to Humans, Volume 68: Silica, Some Silicates, Coal Dust and Para-Aramid Fibrils. International Agency for Research on Cancer, Lyon, France 1997.

22. Bundesgesetzblatt für die Republik Österreich. Jahrgang 2003. 184 Verordnung des Bundesministers für Wirtschaft und Arbeit, mit der die Grenzwerteverordnung 2001 geändert wird (cited 2007 May 9). Available at http://www.ris.bka. gv.at $/$ taweb-cgi $/$ taweb $\mathrm{x}=\mathrm{d} \& 0=\mathrm{r} \& \mathrm{v}=$ bgblpdf $\& \mathrm{~d}=\mathrm{BGBLP}$ $\mathrm{DF} \& \mathrm{I}=3851 \& \mathrm{p}=2$ [in German].

23. Arrêté royal du mars 2002 relatif à la protection de la santé et de la sécurité des travailleurs contre les risques lies à des agents chimiques sur le lieu de travail. Annexe I: Valeurs limites d'exposition professionnelle (cited 2007 May 9). Available at http://www.emploi.belgique.be/WorkArea/showcontent.aspx?id=2946 [in French].

24. Ministerstvo na Truda i Socialnata Politika. Ministerstvo na Zdraveopazvaneto. Naredba no 13 ot 30 dekemvri 2003 za zasztita na rabotesztite ot riskove, svyrzani s ekspoziciâ na himiĉni agenti pri rabota (cited 2007 March 16). Available at http://law.dir.bg/reference.php?f=n13tsp03 [in Bulgarian].

25. Règlement sur la santé et la sécurité du travail (cited 2007 May 10). Available at http://www2.publicationsduquebec. gouv.qc.ca/dynamicSearch/telecharge.php?type $=2 \&$ file $=\%$ 2F\%2FS_2_1\%2FS2_1R19_01.htm [in French].

26. Canadian Legal Information Institute. Chemical Hazards Regulation. Alta.Reg.393/1988(cited2007 May10). Available at http://www.canlii.org/ab/laws/regu/1988r.393/20040430/ whole.html. 
27. The Occupational Health and Safety Regulation. Table of exposure limits for chemical and biological substances (cited 2007 May 10). Available at http:/www2.worksafebc.com/ PDFs/regulation/exposure_limits.pdf.

28. Ministerio de Salud Servicio de Salud Valparaiso - San Antonio Depto. Prog. Sobre el Ambiente. Reglamento sobre Condiciones Sanitarias y Ambientales Básicas en los Lugares de Trabajo (cited 2007 March 16). Available at http://www.ssvsa.cl/ds745.htm [in Spanish].

29. IMA Europe - Industrial Minerals Association. Occupational Exposure Limits - Respirable fraction in EU $25+$ Norway and Switzerland (cited 2007 May 9). Available at http://www.ima-eu.org/OELTABLEJULY06.pdf.

30. Arbejdstilsynet. Wea-Guide. October 2002. Limit values for substances and materials (cited 2007 March 16). Available at http://www.at.dk/graphics/at/engelsk-pdf/at-vejledninger/ gvlisteuk.pdf.

31. Ohtlike ainete piirnormid tőőkeskkonnas. Sotsiaalministri 23. novembri 1998. a määrus nr 57 (cited 2007 March 16). Available at http://trip.rk.ee/cgi-bin/thw?\$7BBASE\%7 $\mathrm{D}=\mathrm{akt} \& \$ \% 7 \mathrm{BOOHTML} \% 7 \mathrm{D}=\operatorname{rtd} \& \mathrm{ID}=\% 27 \mathrm{SOMm}$ RTL_1998,_365,_1552\%27 [in Estonian].

32. Ministry of Social Affairs and Health in Finland. HTP-arvot 2005. Liite 1 (cited 2007 May 9). Available at http://www. ilo.org/pubcgi/links_ext.pl?http://www.stm.fi/Resource.phx/ publishing/store/2005/04/hm1113392554181/passthru.pdf [in Finnish].

33. L'Institut National de Recherche et de sécurité. Valeurs limites d'exposition professionnelle aux agents chimiques en France (cited 2007 May 10). Available at http://www.ilo.org/ pubcgi/links_ext.pl?http://www.inrs.fr/INRS-PUB/inrs01. nsf/inrs01_catalog_view_view/5462CE3DF935FAFBC12571 B20023D726/\$FILE/ed984.pdf [in French].

34. Health and Safety Executive. EH40/2005 Workplace exposure limits. Table 1: List of approved workplace exposure limits (cited 2007 May 22). Available at http://www.hse.gov. uk/coshh/table1.pdf.

35. The Social and Economic Council of the Netherlands (SER). MAC-Waarden. Silicium(di)oxide (cited 2007 March 16). Available at http://www.ser.nl/overdeser/default. asp?desc=mac_waarden_siliciumdioxide [in Dutch].
36. EMLA Környezeti Management és Jog Egyesület. 25/2000. EüM-SzCsM együttes rendelet a munkahelyek kémiai biztonságáról (cited 2007 May 22). Available at http://www. emla.hu/prtr/kembizt25_2000.pdf [in Hungarian].

37. Fulekar MH: Occupational Exposure to Dust in Quartz Manufacturing Industry. Ann Occup Hyg 1999;43:269-73.

38. The Japan Society for Occupational Health. Recommendation of Occupational Exposure Limits (2006-2007). J Occup Health 2006;48:290-306.

39. Informãcija par standarta LVS 89: 2004 Bũtiskajãm prasībãm. Tabula 2. Ķĩmisko vielu aroda skspozĩcijas robežvērtỉbas darba vides gaisam (cited 2007 May 10). Available at http:// osha.lv/legislation/lv/LVS_89_2004Kimisko_vielu_AER.pdf [in Lithuanian].

40. The Registry of Toxic Effects of Chemical Substances: Silica, crystalline - quartz (cited 2007 May 18). Available at http://www.cdc.gov/niosh/rtecs/vv6fd8d0.html.

41. The Registry of Toxic Effects of Chemical Substances: Silica, crystalline - cristobalite (cited 2007 May 18). Available at http://www.cdc.gov/niosh/rtecs/vv6fc548.html.

42. The Registry of Toxic Effects of Chemical Substances: Silica, crystalline - trydymite (cited 2007 May 18). Available at http://www.cdc.gov/niosh/rtecs/vv6fec58.html.

43. Occupational Safety and Health Service Te Ratonga Oranga. Department of Labour Te Tari Mahi. Workplace Exposure Standards (cited 2007 May 18). Available at http://www.osh. dol.govt.nz/order/catalogue/pdf/wes2002.pdf.

44. Arbeidstilsynet. Veiledning om administrative normer for forurensning i arbeidsatmosfære (cited 2007 May 18). Available at http://www.arbeidstilsynet.no/c26983/artikkel/vis. html?tid=28880 [in Norwegian].

45. Southern African Institute for Occupational Hygiene. Occupational Exposure Limits (OELs) for Airborne Pollutants (cited 2007 May 18). Available at http://www.saioh.org/ OELs/dolrl_q-s.htm.

46. Nariadenie Vlády Slovenskej republiky zo 16 januára 2002 o ochrane zdravia pri práci s chemickými faktormi (cited 2007 May 18). Available at http://www.bozpo.sk/bezpecnost/predpis/45_02.pdf [in Slovak].

47. Ministerio de Trabajo Y Asuntos Sociales España. Límites de exposición profesional para agentes químicos en España 
(cited 2007 May 10). Available at http://www.mtas.es/insht/ practice/vlas.htm [in Spanish].

48. Statute Book of the Swedish Work Environment Authority. Occupational Exposure Limit Values and Measures against Air Contaminants (cited 2007 May 22). Available at http:// www.av.se/dokument/inenglish/legislations/eng0517.pdf.

49. SUVAPro Le travail en sécurité. Valeurs limites d'exposition aux postes de travail 2007 (cited 2007 May 22). Available at http://wwwitsp1.suva.ch/sap/its/mimes/waswo/99/pdf/1903-f.pdf [in French].

50. U.S. Department of Labor Occupational Safety and Health Administration. Regulations (Standards - 29 CFR), Table Z-3 Mineral Dusts (cited 2007 May 21). Available at http:// www.osha.gov/pls/oshaweb/owadisp.show_document? p_table $=$ STANDARDS\&p_id $=9994$.

51. California Department of Industrial Relations. Table AC-1. Permissible exposure limits for chemical contaminants (cited 2007 May 22). Available at http://www.dir.ca.gov/ title8/5155table_ac1.html.

52. Department of Consumer and Industry Services. Director's Office. Occupational Health Standards. (cited 2007 May 22). Available at http://www.michigan.gov/documents/CIS_ WSH_part301_35589_7.pdf.

53. Minnesota Department of Labor and Industry. Occupational Safety and Health. Subpart Z - Toxic and Hazardous Substances 1910.1000-Air Contaminants (cited 2007 May 22). Available at http://www.doli.state.mn.us/pdf/pels.pdf.

54. Washington State Department of Labor and Industries. Permissible Exposure Limits for Air Contaminants (cited 2007 May 22). Available at http://www.lni.wa.gov/WISHA/Rules/ respiratoryhazards/PDFs/Table3-ExposureLimits.pdf.

55. Regulation of the Ministry of Labor, Remuneration, and Social Affairs of 2 August 1985 changing the regulation concerning the highest admissible concentrations and volume of agents harmful to health in the workplace environment. Dziennik Ustaw [Law Gazette] 1985, No 40, item 195 [in Polish].

56. Regulation of the Ministry of Labor, Remuneration, and Social Affairs of 18 December 2002 concerning the highest admissible concentrations and volume of agents harmful to health in the workplace environment. Dziennik Ustaw [Law Gazette] 2002, No 217, item 1833 [in Polish].
57. Regulation of the Council of Ministers of 21 August 1959 regarding general hygenic-sanitary conditions in newly built or reconstructed plants. Dziennik Ustaw [Law Gazette] 1959, No 53, item 316 [in Polish].

58. Regulation of the Ministry of Labor, Remuneration, and Social Affairs of 17 March 1976 concerning the highest admissible concentrations and volume of agents harmful to health at the workplace. Dziennik Ustaw [Law Gazette] 1976, No 13, item 77 [in Polish].

59. 2005 TLVs and BEIs Based on Documentation on the Threshold Limit Values for Chemical Substances and Physical Agents and Biological Exposure Indices. American Conference of Governmental Industrial Hygienists, Cincinnati 2005.

60. IARC Monographs on the Evaluation of Carcinogenic Risk to Humans, Volume 42: Silica and Some Silicates. International Agency for Research on Cancer, Lyon, France 1987.

61. Pelucchi C, Pira E, Piolatto G, Coggiola P, Carta P, La Vecchia $\mathrm{C}$ : Occupational silica exposure and lung cancer risk: a review of epidemiological studies 1996-2005. Ann Oncol 2006;17:1039-50.

62. Council Directive 67/548/EEC of 27 June 1967 on the approximation of laws, regulations and administrative provisions relating to the classification, packaging and labelling of dangerous substances.

63. Commission Directive 2004/73/EC of 29 April 2004 adapting to technical progress for the twenty-ninth time Council Directive 67/548/EEC on the approximation of the laws, regulations and administrative provisions relating to the classification, packaging and labelling of dangerous substances.

64. Regulation of the Minister of Health and Social Care of 11 October 1996 concerning carcinogenic factors in the workplace environment and the supervision over the health condition of employees occupationally exposed to these agents. Dziennik Ustaw [Law Gazette] 1996, No 121, item 571 [in Polish].

65. Regulation of the Minister of Health of 1 December 2004 concerning substances, preparations, agents or technological processes with carcinogenic or mutagenic effect in the workplace environment. Dziennik Ustaw [Law Gazette] 2004, No 280 item 2771 [in Polish].

66. PN-ISO 4225:1999: Air quality - General aspects - Vocabulary. Warszawa: Polish Committee for Standardization (PKN); 1999 [in Polish]. 
67. PN-ISO 4225/Ak:1999: Air quality - General aspects — Terminology (national annex). Warszawa: Polish Committee for Standardization (PKN); 1999 [in Polish].

68. PN-EN 1540:2004: Workplace atmospheres — Terminology. Warszawa: Polish Committee for Standardization (PKN); 2004 [in Polish].

69. PN-EN 481:1998: Workplace atmospheres - Size fraction definitions for measurement of airborne particles. Warszawa: Polish Committee for Standardization (PKN); 1998 [in Polish].

70. PN-ISO 7708:2001: Air quality — Particle size fraction definitions for health-related sampling. Warszawa: Polish Committee for Standardization (PKN); 2001 [in Polish].

71. PN-EN 1232:2002: Workplace atmospheres — Pumps for personal sampling of chemical agents - Requirements and test methods. Warszawa: Polish Committee for Standardization (PKN); 2002 [in Polish].

72. PN-EN 13205:2004: Workplace atmospheres — Assessment of performance of instruments for measurement of airborne particle concentration. Warszawa: Polish Committee for Standardization (PKN); 2004 [in Polish].

73. PN-EN 482:2002: Workplace atmospheres - General requirements for the performance of procedures for the measurement of chemical agents. Warszawa: Polish Committee for Standardization (PKN); 2002 [in Polish].

74. PN-Z-04008-7:2002: Air purity protection - Sampling methods - Principles of air sampling in workplace and interpretation of results. Warszawa: Polish Committee for Standardization (PKN); 2002 [in Polish].

75. Regulation of the Minister of Health of 20 April 2005 concerning the tests and measurements in relation to agents harmful to health in the workplace environment. Dziennik Ustaw [Law Gazette] 2005, No 73, item 645 [in Polish].

76. GESTIS Analytical methods for chemical agents at workplaces (cited 2007 June 14). Available at http://www.hvbg. de/e/bia/gestis/analytical_methods/index.html.

77. GESTIS Analytical methods for chemical agents at workplaces. List No 125. Respirable aerosol fraction and gravimetric analysis (cited 2007 June 21). Available at http:// bgia-online.hvbg.de/AMCAW/substance/methoden/125-LAerosols\%20respirable.pdf.
78. GESTIS Analytical methods for chemical agents at workplaces. List No 124. Inhalable aerosol fraction and gravimetric analysis (cited 2007 June 14). Available at http:// bgia-online.hvbg.de/AMCAW/substance/methoden/124-LAerosols\%20inhalable.pdf

79. MDHS 14/3: General methods for sampling and gravimetric analysis of respirable and inhalable dust; Health and Safety Laboratory, UK (cited 2007 June 14). Available at http:// www.hse.gov.uk/pubns/mdhs/pdfs/mdhs14-3.pdf.

80. NIOSH 0600: Respirable particulates, not otherwise regulated (cited 2007 June 21). Available at http://www.cdc.gov/ niosh/nmam/pdfs/0600rev.pdf.

81. NIOSH 0500: Total particulates, not otherwise regulated (cited 2007 June 21). Available at http://www.cdc.gov/niosh/ nmam/pdfs/0500.pdf.

82. OSHA PV2121: Gravimetric determination (cited 2007 June 21). Available at http://www.osha.gov/dts/sltc/methods/partial/pv2121/pv2121.html.

83. L'Institut National de Recherche et de sécurité. MetroPol Fiche 002: Concentration pondérale d'un aérosol sur filter (cited 2007 June 21). Available at http://www.inrs.fr/ [in French].

84. L'Institut National de Recherche et de sécurité. MetroPol Fiche 085: Concentration pondérale d'un aérosol sur mousse tournante (CIP10) (cited 2007 June 21). Available at http:// www.inrs.fr/ [in French].

85. MTA/MA-014/A88: Determinación de materia particulada (total y fracción respirable) en aire - Método gravimétrico; Instituto National de Seguridad e Higiene en el Trabajo (cited 2007 June 14). Available at http://www.mtas.es//insht/ MTA/MA_014_A88.htm [in Spanish].

86. PN-91/Z-04030/05: Air purity protection. Tests for dust. Determination of total dust in workplaces by filtration-gravimetric method. Warszawa: Polski Komitet Normalizacji, Miar i Jakości; 1991 [in Polish].

87. PN-91/Z-04030/06: Air purity protection. Tests for dust. Determination of respirable dust in workplaces by filtrationgravimetric method. Warszawa: Polski Komitet Normalizacji, Miar i Jakości; 1991 [in Polish].

88. PN-91/Z-04018/04: Air purity protection. Tests for free crystalline silica content. Determination of free crystalline silica in total and respirable dust in the presence of silicates in workplaces by colorimetric method. Warszawa: Polski Komitet Normalizacji, Miar i Jakości; 1991 [in Polish]. 
89. PN-91/Z-04018/02: Air purity protection. Tests for free crystalline silica content. Determination of free crystalline silica in total dust in workplaces by infrared absorption spectrophotometry. Warszawa: Polski Komitet Normalizacji, Miar i Jakości; 1991 [in Polish].

90. PN-91/Z-04018/03: Air purity protection. Tests for free crystalline silica content. Determination of free crystalline silica in respirable dust in workplaces by infrared absorption spectrophotometry. Warszawa: Polski Komitet Normalizacji, Miar i Jakości; 1991 [in Polish].

91. GESTIS Analytical methods for chemical agents at workplaces: Crystalline silica (Quartz, Tridymite, Cristobalite) (cited 2007 June 14). Available at http//bgia-online.hvbg.de/ AMCAW/substance/methoden/117-L-Crystalline\%20silica. pdf.

92. GESTIS Analytical methods for chemical agents at workplaces: Quartz (cited 2007 June 14). Available at http:// bgia-online.hvbg.de/AMCAW/substance/methoden/052-LQuartz.pdf.

93. MDHS 101: Crystalline silica in respirable airborne dusts Direct on-filter analyses by infrared spectroscopy and X-ray diffraction. Health and Safety Laboratory, UK (cited 2007 June 14). Available at http://www.hse.gov.uk/pubns/mdhs/ pdfs/mdhs101.pdf.

94. L'Institut National de Recherche et de sécurité. MétroPol Fiche 049: Silice Cristalline par Diffraction des Rayons X (cited 2007 June 14). Available at http://www.inrs.fr/ [in French].

95. MTA/MA-036/A00: Determination of quartz in air - filter membrane method / X-ray diffraction; Instituto National de Seguridad e Higiene en el Trabajo (cited 2007 June 14). Available at http://www.mtas.es//insht/en/MTA/MA_036_ A00_en.htm.

96. MTA/MA - 057/A04: Determinación de sílice libre cristalina en materia particulada (fracción respirable) en aire. Método del filtro de membrana / Espectrofotometría de infrarrojos; Instituto National de Seguridad e Higiene en el Trabajo (cited 2007 June 14). Available at http://www.mtas.es//insht/ MTA/MA_057_A04.htm [in Spanish].

97. NIOSH 7500: Silica, Crystalline, by XRD (filter redeposition) (cited 2007 June 14). Available at http://www.cdc.gov/ niosh/nmam/pdfs/7500.pdf.
98. NIOSH 7601: Silica, crystalline, by VIS (cited 2007 June 14). Available at http://www.cdc.gov/niosh/nmam/ pdfs/7601.pdf.

99. NIOSH 7602: Silica, crystalline, by IR (KBr pellet) (cited 2007 June 14). Available at http://www.cdc.gov/niosh/ nmam/pdfs/7602.pdf.

100. NIOSH 7603: Quartz in coal mine dust, by IR (redeposition) (cited 2007 June 14). Available at http://www.cdc.gov/ niosh/nmam/pdfs/7603.pdf.

101. OSHA ID-142: Quartz and Cristobalite in Workplace Atmospheres (cited 2007 June 14). Available at http://www. osha.gov/dts/sltc/methods/inorganic/id142/id142.html.

102. Foster RD, Walker RF: Quantitative Determination of Crystalline Silica in Respirable-size Dust Samples by Infrared Spectrophotometry. Analyst 1984;109:1117-27.

103. Smith DK: Evaluation of detectability and quantification of respirable crystalline silica by X-ray powder diffraction methods. Powder Diffraction 1997;12(4):200-27.

104. Miles WJ: Chemical methods of analysis for crystalline silica. A critical literature review. Anal Chim Acta 1994;286:3-7.

105. Miles WJ: Issues and Controversy: The Measurement of Crystalline Silica; Review Papers on Analytical Methods. AIHA Journal 1999;60:396-402.

106. Ojima J: Determining of Crystalline Silica in Respirable Dust Samples by Infrared Spectrophotometry in the Presence of Interferences. J Occup Health 2003;45:94-103.

107. Virji MA, Bello D, Woskie SR, Liu XM, Kalil AJ: Analysis of Quartz by FT-IR in Air Samples of Construction Dust. Appl Occup Environ Hyg 2002;17(3):165-75.

108. Jeyaratnam M, Nagar N: Comparison of $\alpha$-Quartz standard Sikron F600 (HSE A9950) with the NIST respirable a-Quartz standard SRM 1878 for bulk and on-filter analysis. Ann Occup Hyg 1993;37(2):167-79.

109. Kauffer E, Moulut JC, Masson A, Grzebyk M: Comparison by X-Ray Diffraction and Infrared Spectroscopy of Two Samples of $\alpha$ Quartz. Ann Occup Hyg 2002;46:409-21.

110. Verma D, Shaw DS: A Comparison of International Silica ( $\alpha$-Quartz) Calibration Standards by Fourier Transform - Infrared Spectrophotometry. Ann Occup Hyg 2001;45:429-35. 
111. Chisholm J: Comparison of Quartz Standards for X-ray Diffraction Analysis: HSE A9950 (Sikron F600) and NIST SRM 1878. Ann Occup Hyg 2005;49(4):351-8.

112. Kauffer E, Masson A, Moulut JC, Lecaque T, Protois JC: Comparison of Direct (X-Ray Diffraction and Infrared Spectrophotometry) and Indirect (Infrared Spectrophotometry) Methods for the Analysis of $\alpha$-Quartz in Airborne Dusts. Ann Occup Hyg 2005;49(8):661-71.

113. Stacey P, Tylee B, Bard D, Atkinson R: The Performance of Laboratories Analysing $\alpha$-Quartz in the Workplace Analysis Scheme for Proficiency (WASP). Ann Occup Hyg 2003;47(4):269-77.
114. Eller PM, Feng HA, Song RS, Key-Schwartz RJ, Esche CA, Groff JM: Proficiency Analytical Testing (PAT) Silica Variability, 1990-1998. Am Ind Hyg Assoc J. 1999;60:533-9.

115. Pickard KJ, Walker RF, West NG: A comparison of X-ray diffraction and infrared spectrophotometric methods for the analysis of $\alpha$-quartz in airborne dusts. Ann Occup Hyg 1985;29:149-67.

116. Maciejewska A, Szadkowska-Stańczyk I, Kondratowicz G: Free crystalline silica: A comparison of methods for its determination in total dusts. Med Pr 2005;56(1):1-8 [in Polish]. 